\title{
Changes in East Asian summer monsoon precipitation during the Holocene deduced from a freshwater flux reconstruction of the Changjiang (Yangtze River) based on the oxygen isotope mass balance in the northern East China Sea
}

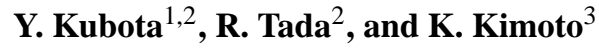 \\ ${ }^{1}$ Department of Geology and Paleontology, National Museum of Nature and Science, 4-1-1, \\ Amakubo, Tsukuba, Ibaraki 305-0005, Japan \\ ${ }^{2}$ Department of Earth and Planetary Science, Graduate School of Science, the University of Tokyo, 7-3-1, \\ Hongo, Bunkyo-ku, Tokyo 113-0033, Japan \\ ${ }^{3}$ Research Institute for Global Change, Japan Agency for Marine-Earth Science and Technology, \\ 2-15 Natsushima-cho, Yokosuka, Kanagawa 237-0061, Japan \\ Correspondence to: Y. Kubota (yoshimi@kahaku.go.jp)
}

Received: 9 March 2014 - Published in Clim. Past Discuss.: 9 April 2014

Revised: 7 November 2014 - Accepted: 9 December 2014 - Published: 17 February 2015

\begin{abstract}
The $\delta^{18} \mathrm{O}$ of seawater $\left(\delta^{18} \mathrm{O}_{\mathrm{w}}\right)$, an indirect indicator of sea surface salinity (SSS), in the northern East China Sea (ECS) is reconstructed for the Holocene using paired analyses of $\mathrm{Mg} / \mathrm{Ca}$ ratio and $\delta^{18} \mathrm{O}$ of planktic foraminiferal tests. According to modern observation, interannual variations in SSS during summer in the northern ECS are mainly controlled by the Changjiang (Yangtze River) discharge, which reflects summer rainfall in its drainage basin. Thus, changes in the summer SSS in the northern ECS are interpreted as reflecting variations in the East Asian summer monsoon (EASM) precipitation in the Changjiang Basin. This interpretation is confirmed by a strong relationship between the SSS in the northern ECS and the Changjiang discharge during the wet season (May-October) based on instrumental salinity records from 1951 to 2000. However, it is difficult to estimate absolute salinity values in the past with high accuracy, because the past salinity- $\delta^{18} \mathrm{O}_{\mathrm{w}}$ regression slope, end member salinity, and $\delta^{18} \mathrm{O}_{\mathrm{w}}$ values are not well understood. Here, we conduct $\delta^{18} \mathrm{O}_{\mathrm{w}}$ mass-balance calculation to estimate the freshwater contribution to the surface water of the northern ECS during the last $7 \mathrm{kyr}$ by assuming a simple mixing between two end members - the seawater and the Changjiang freshwater. The result indicates that there has been no gradual decreasing secular trend in the Changjiang freshwater flux from the middle Holocene to the
\end{abstract}

present day, suggesting that summer insolation in the Northern Hemisphere does not regulate the EASM precipitation in the Changjiang Basin. Instead, internal feedback appears to have been more important during the Holocene. The absence of a decreasing trend in regional summer precipitation over the Changjiang Basin since the middle Holocene is contradictory to Chinese speleothems' $\delta^{18} \mathrm{O}$ records, suggesting that it is not possible to explain orbital changes in Chinese speleothems' $\delta^{18} \mathrm{O}$ during the Holocene by changes in summer precipitation, but that such changes are related to other factors such as changes in the moisture source.

\section{Introduction}

The East Asian summer monsoon (EASM) is generated by land-ocean thermal contrast between Asia and northwestern Pacific. The EASM is normally referred to as a subtropical monsoon encompassing the East Asia including eastern China, Japan, Korea and adjacent marginal seas (e.g., Ding, 2004). In paleo-monsoon studies, high-resolution records of oxygen isotope composition of speleothems from Chinese caves have been receiving wide attention (e.g., Wang et al., 2001), because speleothems can provide long and high- 
resolution speleothem $\delta^{18} \mathrm{O}$ data and their age models, which are based on the Uranium series datings, are of high precision and high resolution. The records of the speleothem $\delta^{18} \mathrm{O}$ have been regarded as a proxy of the EASM precipitation or intensity (e.g., Wang, Y. J. et al., 2001; Yuan et al., 2004; Dykoski et al., 2005; Wang Y. et al., 2005; Cheng et al., 2009), indicating that orbital-scale variations in the speleothem $\delta^{18} \mathrm{O}$ follow the summer insolation curve of the Northern Hemisphere without any obvious time lag $(0.77 \pm 0.45 \mathrm{kyr}$; Wang et al., 2008). Based on these speleothem records, the concept that intensity of the EASM is mainly controlled by the local summer insolation on orbital timescale, as suggested by modeling studies (Kutzbach, 1981; Kutzbach et al., 2008), has been widely accepted (e.g., Cheng et al., 2012). During the Holocene, the speleothem $\delta^{18} \mathrm{O}$ systematically increased by $\sim 2.5 \%$ from the middle Holocene to the late Holocene, which is interpreted as reflecting the decrease in the EASM precipitation in response to the decrease in the local summer insolation (Wang et al., 2001). Recently, however, modern data analogues (Maher and Thompson, 2012) and modeling (Pausata et al., 2011) approaches have suggested that the Chinese speleothem $\delta^{18} \mathrm{O}$ records might not reflect the precipitation amount (amount effect), and that other climate factors such as the moisture source and/or conditions in the moisture source seemed more important. LeGrande and Schmidt (2009) pointed out that water isotopes were better interpreted in terms of regional hydrological cycle changes rather than as indicators of local climate based on a modeling result. Clemens et al. (2010) argued that winter temperature change impacted on the speleothem $\delta^{18} \mathrm{O}$ (meteorological precipitation under cold conditions) and the speleothem $\delta^{18} \mathrm{O}$ records cannot be interpreted as reflecting the EASM signal alone. Maher and Thompson (2012) revisited the interpretation of the Chinese speleothem $\delta^{18} \mathrm{O}$ records using mass-balance calculations and argued that the $\delta^{18} \mathrm{O}$ variations could not be accounted for by summer rainfall changes, rainfall seasonality, or winter cooling, but instead reflected changes in the moisture source, i.e., the Indian Ocean or Pacific. Moreover, precipitation/evaporation ratio deduced from several lake-level studies within the Changjiang (Yangtze River) Basin showed no decreasing trend or even slight increase from early-middle to late Holocene (An et al., 2000), which is inconsistent with the classical interpretation of the speleothem $\delta^{18} \mathrm{O}$ during the Holocene that the speleothem $\delta^{18} \mathrm{O}$ reflects the decrease in EASM precipitation.

Kubota et al. (2010) reported millennial-scale variations in water properties between warm and saline Kuroshio Water and cool and less saline Changjiang Diluted Water (CDW) during the Holocene based on $\mathrm{Mg} / \mathrm{Ca}$ and $\delta^{18} \mathrm{O}$ of Globigerinoides ruber sensu stricto (s.s.) $\left(\delta^{18} \mathrm{O}_{\mathrm{c}}\right)$ at site $\mathrm{KY} 07$ 04-01 (hereafter site KY) in the East China Sea (ECS), and claimed that events of higher (lower) contribution of CDW corresponded to higher (lower) precipitation in Changjiang Basin and hence associated larger (smaller) discharge of the Changjiang freshwater. However, Kubota et al. (2010) only

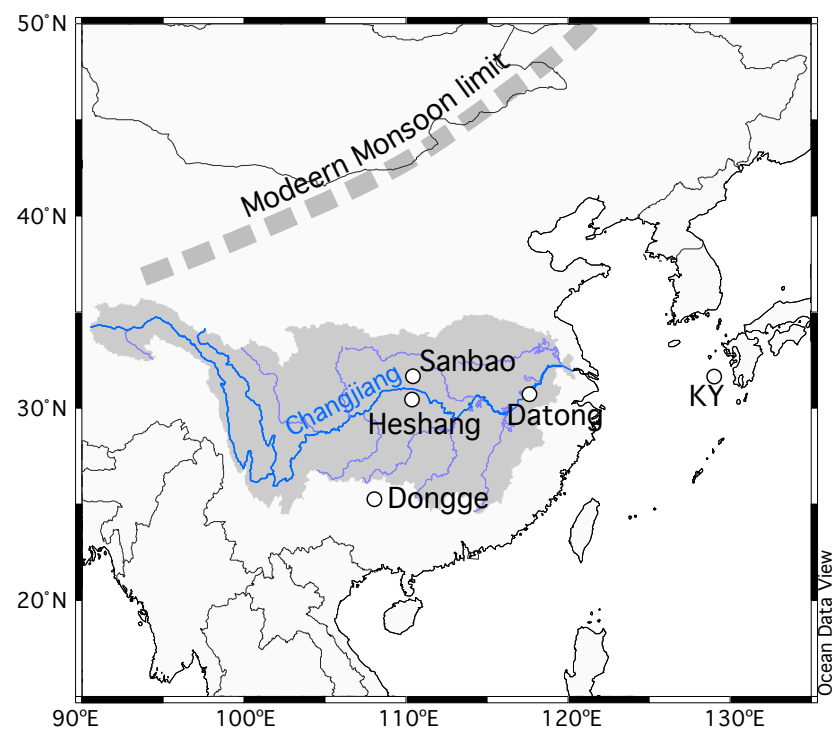

Figure 1. A map showing the Changjiang drainage basin (gray shaded area), Datong hydrological station, cave locations of the speleothem's study, and the core site of KY07-04-01. A dashed gray line represents the modern northern limit of the monsoon front.

reconstructed the variations in relative contribution of the two water masses, and did not discuss the changes in the summer precipitation (or Changiiang freshwater discharge) explicitly. In this study, we calculated relative contribution of the Changjiang freshwater $\left(f_{\mathrm{CFW}}\right)$ to the surface water at site KY in the northern ECS in order to conduct the quantitative reconstruction of the Changjiang discharge during the last $7 \mathrm{kyr}$. In this calculation, temporal changes in end member $\delta^{18} \mathrm{O}_{\mathrm{w}}$ of the water masses, which may affect the $\delta^{18} \mathrm{O}_{\mathrm{w}}$ values at the core site, were taken into consideration. Then, we estimated the summer flux of the freshwater of the Changjiang $\left(Q_{\mathrm{CFW}}\right)$ into the ECS by applying a modern empirical relationship between $f_{\mathrm{CFW}}$ and $Q_{\mathrm{CFW}}$ around the core site. In addition to the data published in Kubota et al. (2010), 107 samples from the Holocene part of core KY were analyzed for both $\mathrm{Mg} / \mathrm{Ca}$ and $\delta^{18} \mathrm{O}_{\mathrm{c}}$ to improve the time resolution.

\section{Oceanographical and climatological setting}

The Changjiang is more than $6300 \mathrm{~km}$ in length and has a catchment area of $1.94 \times 10^{6} \mathrm{~km}^{2}$, and its huge drainage basin covers the greater part of South China (Fig. 1). The annual runoff of the Changiiang is attributed mainly to the rainfall in summer, not snowfall in winter (Chen et al., 1994). The year-to-year runoff of the Changjiang at Datong Datong hydrological station, $\sim 600 \mathrm{~km}$ upstream from the Changjiang river mouth, is correlated with basin-wide precipitation $\left(R^{2}=0.81\right.$; Xu et al., 2010), but monthly runoff lags behind average precipitation by roughly 1 month (Jiang 


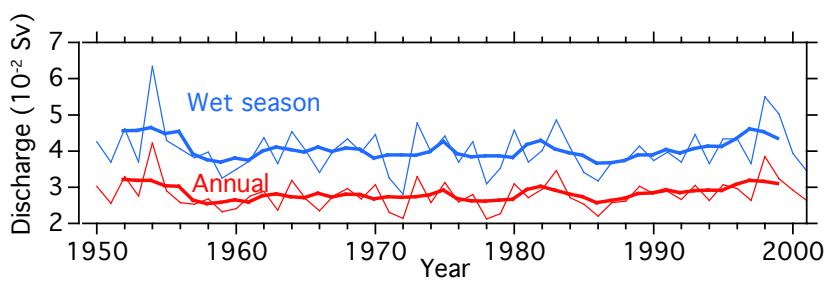

Figure 2. Annual (red) and wet season (May-October) (blue) discharges of the Changjiang at Datong station from 1950 to 2000. Bold lines represent 5-year running mean.

et al., 2007). Annual runoff at Datong is approximately $8900 \times 10^{8} \mathrm{~m}^{3}\left(2.8 \times 10^{-2} \mathrm{~Sv} ; \mathrm{Sv}=10^{6} \mathrm{~m}^{3} \mathrm{~s}^{-1}\right)$ on average during 1961-2000 (Changjiang Water Resources Commission, 2002). The Changjiang discharge shows a remarkable seasonal cycle with the maximum in July and minimum in January. The average water discharge during the wet season (May-October) is $4.0 \times 10^{-2} \mathrm{~Sv}$ at Datong, which accounts for approximately $70 \%$ of annual total discharge (Jiang et al., 2007). The maximum and minimum discharges during the wet season were observed in $1954\left(6.3 \times 10^{-2} \mathrm{~Sv}=160 \%\right.$ of the average value in the past $\sim 50$ years) and 1972 $\left(2.8 \times 10^{-2} \mathrm{~Sv}=70 \%\right.$ of the average value $)$, respectively, during the time period from 1951 to 2000 (Fig. 2).

The Changjiang supplies a huge amount of freshwater into the northern ECS. The ECS is a marginal sea bounded by the Asian continent to the northwest, the island of Taiwan to the southwest, the Ryukyu Islands to the southeast, and Kyushu and the Korean Peninsula to the northeast (Fig. 3). The continental shelf shallower than $200 \mathrm{~m}$ occupies more than $70 \%$ of the entire East China Sea. The Okinawa Trough, of which maximum water depth is greater than $2000 \mathrm{~m}$, stretches from the southwest to northeast in the ECS along the Ryukyu Arc. The ECS connects to surrounding seas through narrow straits or gaps. The waters from the Pacific and South China Sea flow into the ECS through the Yonaguni gap and Taiwan Strait, respectively (Fig. 3). The sill depths of the Tsushima Strait, Taiwan Strait, Yonaguni gap are $\sim 130, \sim 60$, and deeper than $1000 \mathrm{~m}$, respectively.

The Changjiang discharge accounts for $\sim 90 \%$ of the total river discharge to the ECS (Isobe et al., 2002), and sea surface salinity (SSS) in the ECS changes drastically over a year due to the significant influence of the Changjiang discharge caused by the EASM precipitation over the drainage basin. Influence of the Changjiang freshwater on the ECS is larger than the local rainfall over the ECS (Chen et al., 1994), as is also supported by a simulation result by Delcroix and Murtugudde (2002). The Changjiang discharge, which empties into the estuary, forms CDW by mixing with saline ambient water (e.g., Ichikawa and Beardsley, 2002). The structure and pathway of CDW in the Chinese coastal area change seasonally. During winter, CDW flows southward along the Chinese coast. During summer, it has a bimodal structure consist-

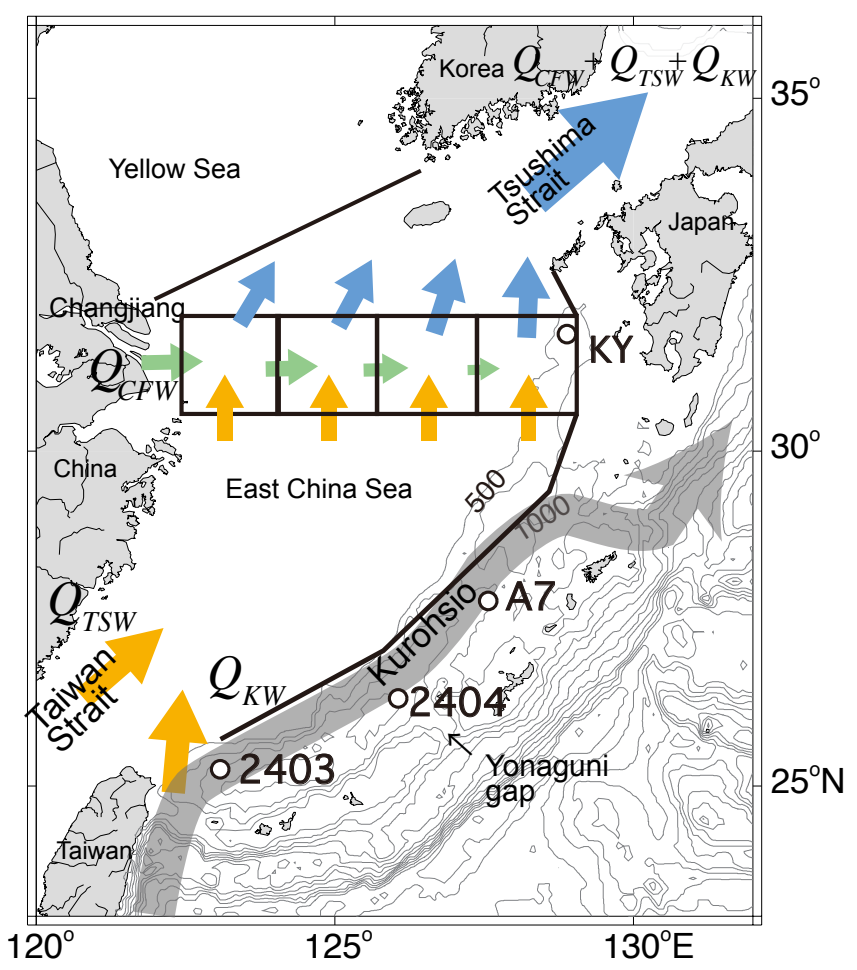

Figure 3. A map showing the simplified modern current system during summer in the East China Sea (ECS). Water fluxes into the ECS shelf are described as $Q_{\mathrm{KW}}, Q_{\mathrm{TSW}}$, and $Q_{\mathrm{CFW}}$. Subscripts KW, TSW, and CFW represent Kuroshio Waters, Taiwan Strait Water, and Changjiang freshwater, respectively. Orange arrows represent fluxes of the Kuroshio Waters and Taiwan Strait Water onto the shelf. Green arrows represent fluxes of Changjiang freshwater of each box. Blue arrows represent fluxes of seawater mixed with the Changjiang freshwater. The gray arrow represents the Kuroshio Current in the Okinawa Trough. Net water exchange between the Yellow and East China seas is not taken into account. The Kuroshio Waters are considered to be intruding to the shelf area mainly through northeastern Taiwan (Chen et al., 1995). Core sites of KY07-04-01 (this study), A7 (Sun et al., 2005), 2404 (Chen et al., 2010), and 2403 (Lin et al., 2006) are denoted as open circles.

ing of a southward coastal jet and a northeastward spread, and the latter eventually reaches the Japan Sea (Mao et al., 1964; Beardsley et al., 1985; Ichikawa and Beardsley, 2002). According to Isobe et al. (2002), nearly all of the river discharge during summer into the ECS is estimated to flow into the Japan Sea. Therefore, the contribution of the Changjiang freshwater transport by the southward coastal jet leaking to the North Pacific is presumably small. Overall, ocean currents on the ECS shelf are directed northeastward with a speed of the order of $\sim 10 \mathrm{~cm} \mathrm{~s}^{-1}$ (Fang et al., 1991; Katoh et al., 2000), suggesting that CDW takes 2-3 months to cross the entire shelf (roughly $700 \mathrm{~km}$ ) from the mouth of the Changjiang to the Tsushima Strait during summer (Isobe and Matsuno, 2008). The CDW, whose thickness during summer is usually 10 to $30 \mathrm{~m}$ in the mid-shelf area (Lie et al., 2003; 


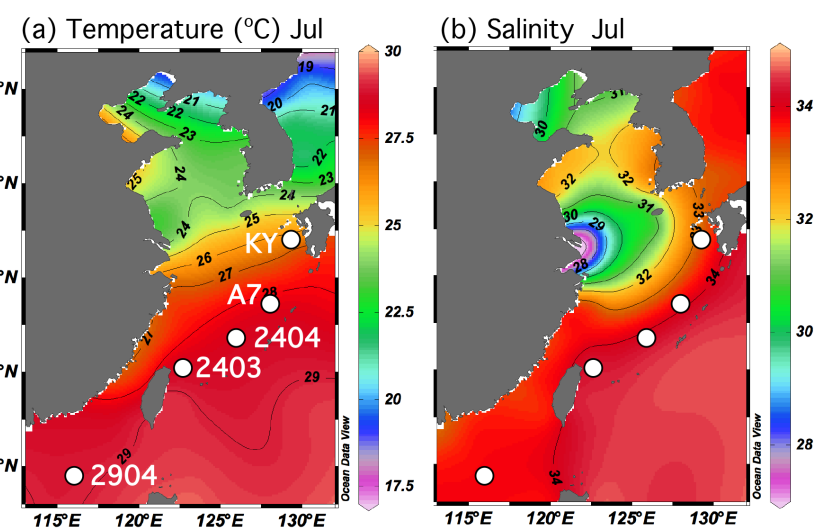

Figure 4. Sea surface temperature (SST) (a) and sea surface salinity (SSS) and (b) in July in the ECS (Locarnini et al., 2010; Antonov et al., 2010) and core locations described in the text. Maps made with Ocean Data View (Schlitzer, 2014).

Isobe and Matsuno, 2008), is characterized by lower salinity and lower temperature compared to the Kuroshio Surface Water. The vertical advection of the cold bottom water that is remnant winter water over the shelf or from the upwelled Kuroshio subsurface water is involved in the formation of CDW during summer (Wang and Chen, 1998).

\section{Material and methods}

A core material of KY07-04-01 $\left(31^{\circ} 38.35^{\prime} \mathrm{N}, 128^{\circ} 56.64^{\prime} \mathrm{E}\right.$; $758 \mathrm{~m}$ water depth), which was retrieved from the Danjo Basin, at the northern edge of the Okinawa Trough (Kubota et al., 2010) was used for $\mathrm{Mg} / \mathrm{Ca}$ and $\delta^{18} \mathrm{O}$ analyses of planktic foraminifer. It is confirmed that CDW can reach to the core site across the shelf break during summer based on ${ }^{226} \mathrm{Ra}$ and ${ }^{228} \mathrm{Ra}$ measurement (Inoue et al., 2012). Inoue et al. (2012) also calculated the relative contribution of the Changiiang freshwater in this area as approximately 2-3\% in July and October using salinity and ${ }^{228} \mathrm{Ra}$ concentration data from 2008 to 2010.

Based on numerous CTD observations, the maximum sea surface temperature (SST) near the core site is $28.4{ }^{\circ} \mathrm{C}$ in August, and the minimum is $17.7^{\circ} \mathrm{C}$ in February (Japan Oceanographic Data Center: JODC). On the other hand, SSS reaches its maximum of 34.7 in February and decreases to its minimum of 33.0 in July, when the maximum discharge of the Changjiang occurs (Fig. 4). Lower SSS during summer indicates that the river runoff due to the EASM precipitation dominates over the seasonal changes of the Kuroshio Current, which works for increasing salinity during summer, when its volume transport is highest. As is shown in Fig. 4, spatial patterns of SST and SSS during summer are characterized by lower SST and SSS in the western part and higher SST and SSS in the eastern part in the northern ECS. The Kuroshio Current penetrates the ECS and flows along the

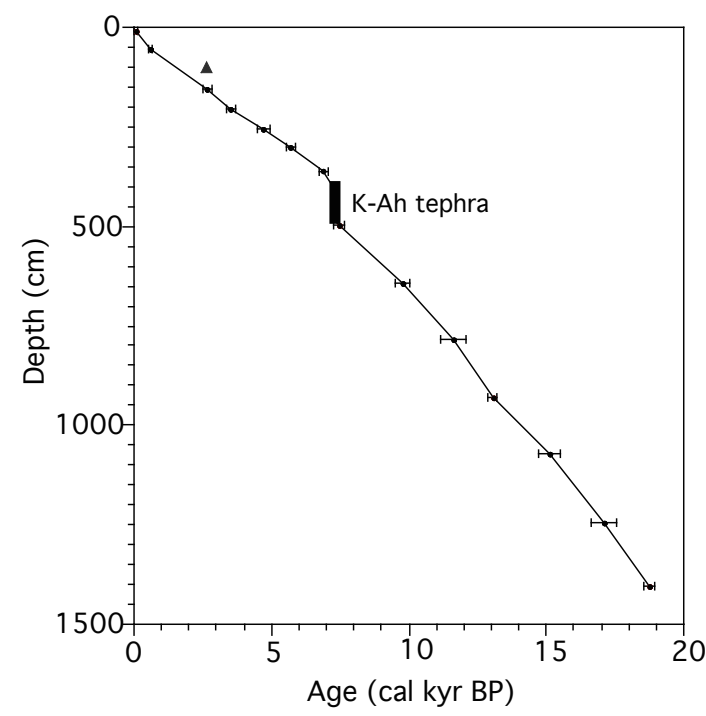

Figure 5. A depth versus calendar age diagram for core KY07-0401. Solid circles represent radiocarbon age control points obtained from planktic foraminiferal tests listed in Table 1. The triangle represents datum rejected for the age model because it deviated from the trend; the bars represent a $2 \sigma$ error; the thick vertical bar represents the interval corresponding to the $\mathrm{K}$-Ah ash layer.

shelf break from southwest to northeast throughout a year and has a major impact on SSS in the Okinawa Trough. However, the influence of the Kuroshio Current on SSS is limited to the area where the main Kuroshio axis lies, and the freshwater discharge of the Changjiang mainly controls SSS at the studied site, as explained later in the text.

The age model of core KY was established based on planktic foraminiferal ${ }^{14} \mathrm{C}$ (14 horizons) and $\mathrm{K}-\mathrm{Ah}$ ash layer (Fig. 5), which was described in detail in Kubota et al. (2010). For isotopes and trace element analyses, approximately 30 to $40 \mathrm{G}$. ruber s.s. specimens were picked and crushed to homogenize. After being cleaned by Milli-Q water and methanol, approximately $50-70 \mu \mathrm{g}$ of foraminiferal samples was separated and used for the oxygen isotope analysis. The $\delta^{18} \mathrm{O}$ of $G$. ruber was measured by a Finnigan MAT 252 stable isotope ratio mass spectrometer with a Kiel III carbonate device at the Mutsu Institute for Oceanography at the Japan Agency of Marine and Science and Technology (JAMSTEC) and at the University of Tokyo. The reproducibility of the measurement is better than $\pm 0.05 \%$ o $(1 \sigma)$ for $\delta^{18} \mathrm{O}$ as determined by replicate measurements of international standards NBS-19 (RM8544 limestone).

After the samples were cleaned by means of "reductive" cleaning protocols for $\mathrm{Mg} / \mathrm{Ca}$ analysis (Boyle and Keigwin, 1985), $\mathrm{Mg} / \mathrm{Ca}$ analysis was performed with a Thermo Finnigan ELEMENT 2, a high-resolution single-collector inductively coupled plasma mass spectrometer (HR-ICP-MS), at Mutsu Institute for Oceanography, JAMSTEC. Isotopes of three elements $\left({ }^{24} \mathrm{Mg},{ }^{44} \mathrm{Ca},{ }^{48} \mathrm{Ca},{ }^{55} \mathrm{Mn}\right)$ were analyzed us- 


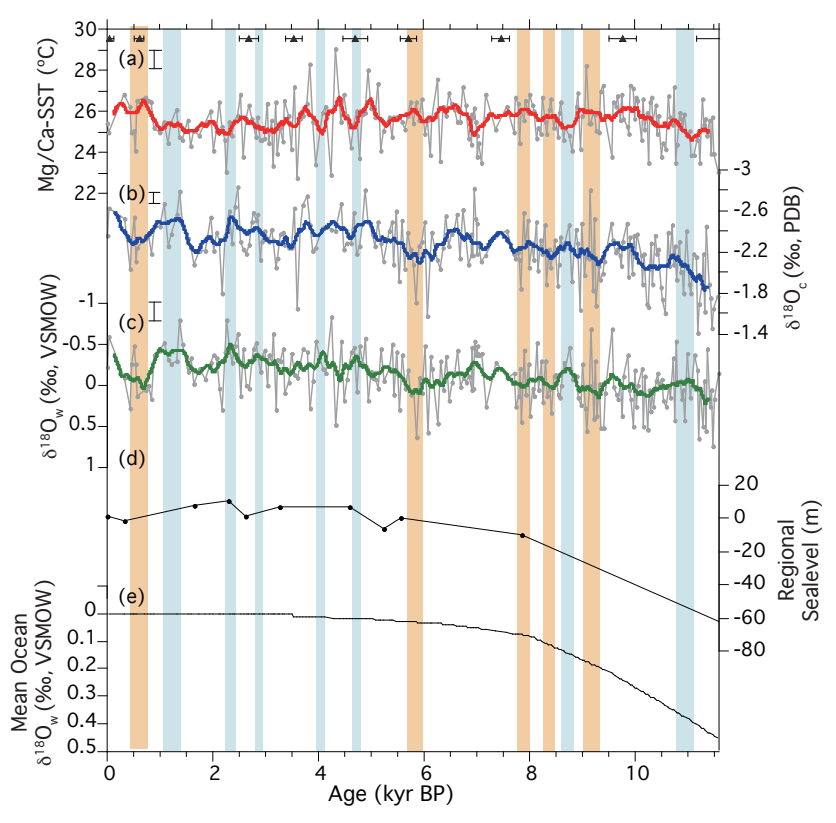

Figure 6. Results of reconstructions of temporal variations in (a) $\mathrm{Mg} / \mathrm{Ca}$-derived SST, (b) $\delta^{18} \mathrm{O}_{\mathrm{c}}$, (c) $\delta^{18} \mathrm{O}_{\mathrm{w}}$ of core KY07-0401. Errors are represented as bars. Bold lines in (a) to (c) represent 300-year average. (d) Time series of regional sea-level record in the East China Sea (Saito et al., 1998). (e) Temporal changes in global mean ocean $\delta^{18} \mathrm{O}_{\mathrm{w}}$ (Waelbroeck et al., 2002). ${ }^{14} \mathrm{C}$ age controlling points of core KY07-04-01 are represented as triangles in the top part of the plot with $2 \sigma$ errors. Brown and blue bars represent higher and lower $\delta^{18} \mathrm{O}_{\mathrm{W}}$ intervals for core KY07-04-01 (Kubota et al., 2010).

ing Sc as the internal standard (Uchida et al., 2008). Four working standards were prepared by successive dilutions of stock-standard solutions to match the concentrations of $\mathrm{Ca}$ (20 ppb, $100 \mathrm{ppb}, 500 \mathrm{ppb}, 2 \mathrm{ppm})$ and $\mathrm{Mg}(0.05,0.2,1.0$, $5 \mathrm{ppb}$ ) covering ranges of the $\mathrm{Ca}$ and $\mathrm{Mg}$ concentrations of all samples. The Milli-Q water in our laboratory was shown to have blank concentrations of below the lowest concentration of the standard solution (e.g., $0.05 \mathrm{ppb}$ for $\mathrm{Mg}$ ) for the elements studied ( $\mathrm{Mg}, \mathrm{Ca}$, and $\mathrm{Mn}$ ).

The precision of replicate analyses of the working standard for $\mathrm{Mg} / \mathrm{Ca}$ is better than $\pm 0.09 \mathrm{mmol} \mathrm{mol}^{-1}$, corresponding to $\pm 0.3^{\circ}$ in temperature scale. As reported by Barker et al. (2003), the sample cleaned by means of the reductive cleaning method of Boyle and Keigwin (1985) gave lower values of $\mathrm{Mg} / \mathrm{Ca}$ (by average approximately $10-15 \%$ ) than those cleaned via the oxidative cleaning procedure of Elderfield and Ganssen (2000). Most of the samples of core KY were cleaned by means of reductive methods, but 38 samples in the Holocene section were cleaned using oxidative methods (Kubota et al., 2010). To verify difference of $\mathrm{Mg} / \mathrm{Ca}$ values between reductive and oxidative cleaning methods in core KY, 15 randomly selected samples were re-picked and cleaned by means of both cleaning methods. The results in- dicate that $\mathrm{Mg} / \mathrm{Ca}$ values with oxidative cleaning methods show, on average, $0.73^{\circ} \mathrm{C}$ higher values than those with reductive cleaning methods on the temperature scale. Thus, in this study, the SST values derived from $\mathrm{Mg} / \mathrm{Ca}$ values via oxidative methods have $0.73^{\circ} \mathrm{C}$ subtracted. Detailed discussions are described in the Supplement. A standard deviation of the differences in $\mathrm{Mg} / \mathrm{Ca}$ and temperature for 36 randomly selected samples is $0.20 \mathrm{mmol} \mathrm{mol}^{-1}$ (i.e., $0.45^{\circ} \mathrm{C}$ ).

The calcification depth of $G$. ruber s.s. is estimated to be upper $30 \mathrm{~m}$ of the water column based on a study of $\delta^{18} \mathrm{O}$ from surface and downcore sediment samples from the South China Sea (Wang, 2000). A plankton tow observation showed that G. ruber was abundant during warmer month, i.e., in June, August, and October in the vicinity of the core site in the northern ECS, which probably responded to the arrival of nutrient-rich (also less saline) CDW (Yamasaki et al., 2010). Thus, this species is suitable for reconstructing the summer freshwater discharge in the past. The surface salinity around the core site begins to decrease in June, associated with the arrival of CDW, and the contribution of CDW is mostly dispersed in November. Here, a main calcification season of $G$. ruber is considered to be June through October. As is explained later, this estimate is reasonable based on the temperature estimate of a core top sample.

\section{Results}

\subsection{Mg / Ca SST}

$\mathrm{Mg} / \mathrm{Ca}$ analysis of G. ruber s.s. was carried out for core $\mathrm{KY}$ at intervals of approximately $2.5-5 \mathrm{~cm}$ (equivalent to approximately 30-60 years) for the time interval of $11.6 \mathrm{kyr} B P$ to the present. The measured $\mathrm{Mg} / \mathrm{Ca}$ values were converted to SST using an equation developed for $G$. ruber in the South China Sea (Hastings et al., 2001). When using this equation, the core top (pilot core for site KY) sample yields a temperature of $25.4{ }^{\circ} \mathrm{C}$, which is close to the modern seasonally averaged temperature from June to October at a depth ranging between the surface and $30 \mathrm{~m}$ near the core site (i.e., $25.7^{\circ} \mathrm{C}$ ) (the seasonally averaged temperature data are statistically processed by JODC based on observational data from 1906 to 2003, which are available at http://jdoss1.jodc.go.jp/vpage/scalar_j.html). For core KY, the effect of preferential removal of $\mathrm{Mg}^{2+}$ from foraminiferal calcite on $\mathrm{Mg} / \mathrm{Ca}$ values due to dissolution on the seafloor (e.g., Dekens et al., 2002, and references therein) is considered to be negligible because the water depth of the core site $(758 \mathrm{~m})$ is well above the modern lysocline (approximately $1600 \mathrm{~m}$ ) in the ECS. Even if a Mg / Ca calibration with correction for the dissolution effect of the Pacific (Dekens et al., 2002) is applied to $\mathrm{Mg} / \mathrm{Ca}$ values of the core top sample, the corrected temperature of $25.6^{\circ} \mathrm{C}$ makes only a $0.2^{\circ} \mathrm{C}$ difference from the non-corrected temperature. Thus, temperature errors derived from $\mathrm{Mg} / \mathrm{Ca}$ calibration are smaller 
than the $\mathrm{Mg} / \mathrm{Ca}$ temperature estimation errors of $\pm 0.45^{\circ} \mathrm{C}$ stemming from heterogeneity of the samples.

Temporal variations of $\mathrm{Mg} / \mathrm{Ca}$-derived SST during the Holocene are shown in Fig. 6. During the early Holocene from 11.6 to $10 \mathrm{kyr} \mathrm{BP}$, SST increased from $\sim 24$ to $26.5^{\circ} \mathrm{C}$. On the other hand, average SSTs in every $2 \mathrm{kyr}$ from 10 to 0 kyr BP mark constant values of $25.6-25.7^{\circ} \mathrm{C}$. Thus, there is no long-term SST trend after $10 \mathrm{kyr} \mathrm{BP}$, whereas multicentennial- to millennial-scale variations are found in the SST record. The amplitudes of the SST variations were especially large during the interval of 5 to $3 \mathrm{kyr}$ BP. SSTs were cooler than the $1 \sigma$ error $\left(0.45^{\circ} \mathrm{C}\right)$ at $11.6-10.9,7.0-6.9$, $4.1,3.2-3.0,2.4-2.1$, and $1.7-1.5 \mathrm{kyr} \mathrm{BP}$, while they were warmer than the $1 \sigma$ error at 10.1-9.8, 9.1-9.0, 8.0-7.9, 6.76.5, 6.4-6.3, 5.9-5.8, 4.9-5.1, 4.5-4.2, 3.8-3.7, 0.8-0.6, and $0.4-0.2 \mathrm{kyr}$ BP. The additional $\mathrm{Mg} / \mathrm{Ca}$ analyses to Kubota et al. (2010) confirmed the several cooler intervals at $\sim 11.1$, 7.0, and $1.7 \mathrm{kyr}$ BP reported in their previous study.

\subsection{Calculation of oxygen isotope ratio of seawater in the northern ECS}

Oxygen isotope ratios of ambient seawater $\left(\delta^{18} \mathrm{O}_{\mathrm{w}}\right)$ values (Fig. 6c) were calculated from using the following $\delta^{18} \mathrm{O}-$ temperature relationship (Shackleton, 1974) using $\delta^{18} \mathrm{O}_{c}$ and $\mathrm{Mg} / \mathrm{Ca}$ SST (Fig. 6b).

$T=16.9-4.38\left(\delta^{18} \mathrm{O}_{\mathrm{c}}-\delta^{18} \mathrm{O}_{\mathrm{w}}\right)+0.10\left(\delta^{18} \mathrm{O}_{\mathrm{c}}-\delta^{18} \mathrm{O}_{\mathrm{w}}\right)^{2}$

The random error in $\delta^{18} \mathrm{O}_{\mathrm{w}}$ is estimated to be $\pm 0.12 \%$ o $(1 \sigma)$, based on error propagation from $\delta^{18} \mathrm{O}_{\mathrm{c}}$ and $\mathrm{Mg} / \mathrm{Ca}$ SST. During the Holocene, amplitudes of multi-centennialto millennial-scale oscillations of $\delta^{18} \mathrm{O}_{\mathrm{w}}$ at site $\mathrm{KY}$ are superimposed on the long-term decrease in $\delta^{18} \mathrm{O}_{\mathrm{w}}$ from the early Holocene to present $\left(\sim 0.26 \%\right.$ o). The $\delta^{18} \mathrm{O}_{\mathrm{w}}$ values are affected by both global and regional factors. As the global sea level continued to rise until $\sim 6 \mathrm{kyr}$ BP (Fig. 6e), our $\delta^{18} \mathrm{O}_{\mathrm{w}}$ data set contains the global signal until then. When the global ice volume effect is subtracted from $\delta^{18} \mathrm{O}_{\mathrm{w}}$ of core KY using the mean ocean $\delta^{18} \mathrm{O}_{\mathrm{w}}$ curve of Waelbroeck et al. (2002), lower $\delta^{18} \mathrm{O}_{\mathrm{w}}$ intervals deviating by more than $1 \sigma( \pm 0.12 \%)$ from the average value were recognized at 11.2-10.6, 8.7, 4.8-4.7, 4.1-4.10, 2.9-2.8, 2.5-2.3, and 1.5$0.9 \mathrm{kyr} \mathrm{BP}$, while higher $\delta^{18} \mathrm{O}_{\mathrm{w}}$ intervals deviating by more than $1 \sigma$ from the average were recognized at 9.3-9.2, 8.9, 8.4, 8.0-7.7, 5.9-5.6, and 0.8-0.4 kyr BP. Among these intervals, the lower $\delta^{18} \mathrm{O}_{\mathrm{w}}$ intervals at $\sim 8.7(8.8 \mathrm{kyr} \mathrm{BP}$ in Kubota et al., 2010), 4.7, and $2.9 \mathrm{kyr} B \mathrm{BP}$ and the higher $\delta^{18} \mathrm{O}_{\mathrm{w}}$ intervals at 9.3, 8.4 (8.3 kyr BP in Kubota et al., 2010), 5.9 (6.0 kyr BP in Kubota et al., 2010), and 0.7-0.4 kyr BP were reported by Kubota et al. (2010). The higher $\delta^{18} \mathrm{O}_{\mathrm{w}}$ intervals at $8.9,8.0-7.9,5.9-5.8$, and $0.8-0.6 \mathrm{kyr} \mathrm{BP}$ coincide with warmer SST intervals described in the previous subsection, and lower $\delta^{18} \mathrm{O}_{\mathrm{w}}$ intervals at 11.2-10.9, 4.1, and 2.4$2.3 \mathrm{kyr}$ BP coincide with cooler SST events. Basically, higher $\delta^{18} \mathrm{O}_{\mathrm{w}}$ intervals tend to coincide with warmer SST peaks, while lower $\delta^{18} \mathrm{O}_{\mathrm{w}}$ intervals tend to coincide with cooler SST peaks on a multi-centennial to millennial timescale.

\subsection{Estimation of relative contribution of freshwater in the northern ECS from $\delta^{18} \mathrm{O}_{w}$}

In the modern ocean, $\delta^{18} \mathrm{O}_{\mathrm{w}}$ of the surface water tracks regional freshwater balance and water mass exchange (e.g., Jacobs et al., 1985). In most oceans, a strong correlation between $\delta^{18} \mathrm{O}_{\mathrm{w}}$ and salinity is observed. However, the relationship between $\delta^{18} \mathrm{O}_{\mathrm{w}}$ and salinity is restricted on a regional scale because of spatiotemporal changes in associated water masses and their end member $\delta^{18} \mathrm{O}_{\mathrm{w}}$ values. Modeling studies involving water isotope $\left(\delta^{18} \mathrm{O}\right.$ and $\left.\delta \mathrm{D}\right)$ tracers in the global-scale hydrological cycle have pointed out that changes in end member $\delta^{18} \mathrm{O}_{\mathrm{w}}$ values should be taken into account to reconstruct the past salinity change (Schmidt et al., 2007; LeGrande and Schmidt, 2009). In the ECS, a $1 \%$ decrease in the $\delta^{18} \mathrm{O}_{\mathrm{w}}$ of freshwater causes underestimates of the salinity by 5 units when the $\delta^{18} \mathrm{O}_{\mathrm{w}}$-salinity slope is kept at $0.2 \% / 1$. Although precise reconstruction of the absolute salinity value for the past is difficult, it is possible to estimate the flux of the freshwater by a calculation that uses the $\delta^{18} \mathrm{O}_{\mathrm{w}}$ of the endmember water masses instead of converting to the salinities. This technique is especially useful in semi-closed marginal seas such as the ECS. As described in Sect. 4.3, the end members of each water mass can be simplified in the ECS, and the contribution of freshwater can then be calculated.

As the sill depth of the Taiwan Strait is shallow, the circulation regime in the ECS highly depends on the sea-level change and associated topographic change (Uehara et al., 2002; Kao et al., 2006). Thus, in this study, the reconstruction of the Changjiang freshwater contribution and flux were conducted for the time interval of $7 \mathrm{kyr}$ BP to present, when the sea level and associated geography stayed relatively the same compared to the present and the ocean surface current in the ECS should have been more or less the same as the present (Uehara et al., 2002). In modern ECS, four water masses - the Kuroshio Surface Water (KSW), Kuroshio Subsurface Water (KSSW), Changjiang Diluted Water (CDW), and Taiwan Strait Warm Water (TSW) - are prominent (Zhang et al., 2007, and references therein). KSW and KSSW originate from the Kuroshio Current, and TSW comes from the South China Sea through the Taiwan Strait. The characteristic hydrographic variables, such as temperatures and salinities, of those four water bodies are listed in Table 1 for comparison. Here, the Changjiang freshwater (CFW) is used instead of CDW for $\delta^{18} \mathrm{O}_{\mathrm{w}}$ balance calculation at site $\mathrm{KY}$ because it is easier to estimate the end member of CFW than that of CDW. 
Table 1. Modern temperature, salinity, and $\delta^{18} \mathrm{O}_{\mathrm{w}}$ values for water masses averaged from June to October in a $1^{\circ} \times 1^{\circ}$ box noted in the column "Areas". Data are from monthly mean data statistically processed by the Japan Ocean Data Center. $\delta^{18} \mathrm{O}_{\mathrm{w}}$ values are converted from salinity values using the present-day relation equation $\delta^{18} \mathrm{O}_{\mathrm{w}}=0.203 S-6.76$ by Oba (1990).

\begin{tabular}{|c|c|c|c|c|c|c|c|c|}
\hline & $\begin{array}{r}\text { Temperature } \\
\left({ }^{\circ} \mathrm{C}\right)\end{array}$ & $\begin{array}{r}\text { Standard } \\
\text { deviation }\end{array}$ & Salinity & $\begin{array}{r}\text { Standard } \\
\text { deviation }\end{array}$ & $\begin{array}{r}\delta^{18} \mathrm{O}_{\mathrm{w}} \\
(\%)\end{array}$ & $\begin{array}{r}\text { Standard } \\
\text { deviation }\end{array}$ & $\begin{array}{r}\text { Areas } \\
(\mathrm{m})\end{array}$ & Depth \\
\hline KSW & 28.03 & 0.45 & 34.23 & 0.16 & 0.19 & 0.06 & $\begin{array}{r}24^{\circ}-25^{\circ} \mathrm{N} \\
122^{\circ}-123^{\circ} \mathrm{E}\end{array}$ & 0 \\
\hline KSSW & 20.89 & 0.80 & 34.71 & 0.07 & 0.29 & 0.01 & $\begin{array}{r}24^{\circ}-25^{\circ} \mathrm{N} \\
122^{\circ}-123^{\circ} \mathrm{E}\end{array}$ & 100 \\
\hline $\mathrm{CDW}$ & 21.53 & 0.88 & 27.31 & 1.74 & -1.22 & 0.35 & $\begin{array}{r}31^{\circ}-32^{\circ} \mathrm{N} \\
122^{\circ}-123^{\circ} \mathrm{E}\end{array}$ & 0 \\
\hline TSW & 26.13 & 0.26 & 33.89 & 0.08 & 0.10 & 0.02 & $\begin{array}{r}24^{\circ}-25^{\circ} \mathrm{N} \\
119^{\circ}-120^{\circ} \mathrm{E}\end{array}$ & $0-30$ \\
\hline
\end{tabular}

Thus, the $\delta^{18} \mathrm{O}_{\mathrm{w}}$ of the surface water at site $\mathrm{KY}\left(\delta^{18} \mathrm{O}_{\mathrm{KY}}\right)$ can be explained by the mixing of the $\delta^{18} \mathrm{O}_{\mathrm{w}}$ including precipitation and evaporation in the ECS as expressed as follows:

$$
\begin{aligned}
& \delta^{18} \mathrm{O}_{\mathrm{CFW}} \cdot f_{\mathrm{CFW}}+\delta^{18} \mathrm{O}_{\mathrm{KSW}} \cdot f_{\mathrm{KSW}}+\delta^{18} \mathrm{O}_{\mathrm{KSSW}} \cdot f_{\mathrm{KSSW}} \\
& +\delta^{18} \mathrm{O}_{\mathrm{TSW}} \cdot f_{\mathrm{TSW}}+\delta^{18} \mathrm{O}_{\mathrm{P}} \cdot f_{\mathrm{P}}-\delta^{18} \mathrm{O}_{\mathrm{E}} \cdot f_{\mathrm{E}}= \\
& \delta^{18} \mathrm{O}_{\mathrm{KY}} \\
& f_{\mathrm{CFW}}+f_{\mathrm{KSW}}+f_{\mathrm{KSSW}}+f_{\mathrm{TSW}}+f_{\mathrm{P}}-f_{\mathrm{E}}=1,
\end{aligned}
$$

where $f$ denotes the relative contribution of each water mass. Subscripts CFW, KSW, KSSW, TSW, P, E, and KY denote the Changjiang freshwater, Kuroshio Surface Water, Kuroshio Subsurface Water, Taiwan Strait Water, precipitation over the ECS, evaporation over the ECS, and the KY site, respectively.

First, consider the effect of the precipitation and evaporation in Eq. (2). At present, precipitation over the entire ECS is $1.9 \times 10^{-2} \mathrm{~Sv}$ from June to October, while evaporation is $1.2 \times 10^{-2} \mathrm{~Sv}$ during the same season (Chen et al., 1994). Modern $\delta^{18} \mathrm{O}_{\mathrm{P}}$ in the East China Sea ranges from -6 to $-10 \%$ based on Global Network of Isotopes in Precipitation (GNIP) observations (IAEA, 2001). Then, $\delta^{18} \mathrm{O}_{\mathrm{E}}$ is estimated to be -6 to $-11 \%$ or the range of the $\delta^{18} \mathrm{O}_{\mathrm{P}}=-6$ to $-10 \%$ based on mass-balance consideration using Eqs. (2) and (3), with values for the each end member listed in Table 1. Considering a much smaller contribution from the net precipitation flux $\left(f_{\mathrm{P}}-f_{\mathrm{E}}<0.5 \%\right)$ than from the other factors in Eq. (3), the terms of $\left(\delta^{18} \mathrm{O}_{\mathrm{P}} \times f_{\mathrm{P}}-\delta^{18} \mathrm{O}_{\mathrm{E}} \times f_{\mathrm{E}}\right)$, which are estimated to be $<0.05 \%$, are therefore negligible in Eq. (3).

For further simplifying Eqs. (2) and (3), we assume a simple water mixing between the freshwater and seawater in the ECS as follows. KSW, KSSW, and TSW were treated together as a single end member and called Kuroshio and Taiwan Strait Water $(\mathrm{KTW}=\mathrm{KSW}+\mathrm{KSSW}+\mathrm{TSW})$ in this study, because modern values of $\delta^{18} \mathrm{O}_{\mathrm{KSW}}, \delta^{18} \mathrm{O}_{\mathrm{KSSW}}$, and $\delta^{18} \mathrm{O}_{\mathrm{TSW}}$ are all within approximately $0.2 \pm 0.09 \%$ and show much higher values than an extremely low $\delta^{18} \mathrm{O}_{\mathrm{CFW}}$ value (approximately $-7 \%$ ). For the water mixing in the ECS, we assume the following situation. KSW and KSSW flow into the ECS shelf from the northeast of Taiwan (Isobe, 2008), and TSW enters the ECS through the Taiwan Strait. $\mathrm{CFW}$ as the other end member increases its salinity by mixing with KTW while traveling northeastward on the shelf, finally reaching site KY.

Based on a direct measurement of the flow speeds in the Taiwan Strait, the flux of TSW $Q_{\mathrm{TSW}}(\mathrm{Sv})$ is reported to be $1.4 \mathrm{~Sv}$ during summer (Isobe, 2008). In contrast, the flux of the KSW $\left(Q_{\mathrm{KSW}}\right)+\mathrm{KSSW}\left(Q_{\mathrm{KSSW}}\right)$ can be estimated to be $1.2 \mathrm{~Sv}$ by the difference in the water flux between the Taiwan Strait $(1.4 \mathrm{~Sv})$ and Tsushima Strait $(2.6 \mathrm{~Sv})$ assuming the connectivity of the volume transports between the Taiwan and Tsushima straits (Isobe, 2008). Thus, $Q_{\mathrm{TSW}}:\left(Q_{\mathrm{KSW}}+Q_{\mathrm{KSSW}}\right)$ is close to $1: 1$ during summer. A proportion of KSW and KSSW that move onto the shelf is estimated as $Q_{\mathrm{KSW}}: Q_{\mathrm{KSSW}} \sim 1: 1$ (Chen and Wang, 1999). Finally, $Q_{\mathrm{TSW}}=2 Q_{\mathrm{KSW}}=2 Q_{\mathrm{KSSW}}$ is obtained. An uncertainty stemming from changes in the mixing ratio will be discussed later in the next section.

Thus, changes in $\delta^{18} \mathrm{O}_{\mathrm{w}}$ at site $\mathrm{KY}\left(\delta^{18} \mathrm{O}_{\mathrm{KY}}\right)$ can be explained by mixing of two end members of $\delta^{18} \mathrm{O}_{\mathrm{w}}-\mathrm{CFW}$ being one and KTW the other - as follows:

$\delta^{18} \mathrm{O}_{\mathrm{CFW}} \cdot f_{\mathrm{CFW}}+\delta^{18} \mathrm{O}_{\mathrm{KTW}} \cdot f_{\mathrm{KTW}}=\delta^{18} O_{\mathrm{KY}}$,

$f_{\mathrm{CFW}}+f_{\mathrm{KTW}}=1$,

where subscript CFW and KTW denote Changjiang freshwater and Kuroshio and Taiwan Strait Water, respectively.

\subsubsection{Reconstruction of temporal changes in $\delta^{18} \mathrm{O}_{\mathrm{W}}$ of end member of the KTW}

In the southern ECS, three data sets of SST and $\delta^{18} \mathrm{O}_{\mathrm{w}}$, which were calculated from $\mathrm{Mg} / \mathrm{Ca}$ and $\delta^{18} \mathrm{O}$ of G. ruber, are available as representing the end member of KSW, namely from cores MD01-2403 (hereafter 2403) $\left(25.3^{\circ} \mathrm{N}, 123.2^{\circ} \mathrm{E}\right.$; 
water depth of $1420 \mathrm{~m}$ : Lin et al., 2006), MD01-2404 (hereafter 2404$)\left(26.4^{\circ} \mathrm{N}, 125.5^{\circ} \mathrm{E}\right.$; water depth of $1397 \mathrm{~m}$ : Chen et al., 2010), and A7 $\left(126^{\circ} 48.7^{\prime} \mathrm{E}, 27^{\circ} 49.2^{\prime} \mathrm{N}\right.$; water depth of $1264 \mathrm{~m}$ : Sun et al., 2005) (Fig. 4). All of these sites are located under the main path of the Kuroshio Current. With the same equation (Hastings et al., 2001) to convert $\mathrm{Mg} / \mathrm{Ca}$ to SST, core top measurements of $\mathrm{Mg} / \mathrm{Ca}$ at 2403 and $\mathrm{A} 7$ yield $27.6^{\circ} \mathrm{C}$ and $26.6^{\circ} \mathrm{C}$, respectively (Lin et al., 2006; Sun et al., 2005), which are within the present-day average temperature of $28.0 \pm 0.7^{\circ} \mathrm{C}(1 \sigma)$ and $27.5 \pm 1.0^{\circ} \mathrm{C}(1 \sigma)$ during summer (June to October) at a water depth ranging from the surface to $30 \mathrm{~m}$ at each site (JODC). Although SST of the core top sample at site 2404 is not available, average SST from 2 to $0 \mathrm{kyr} \mathrm{BP}$ is $27.2^{\circ} \mathrm{C}$ (Chen et al., 2010), which is within the average summer temperature of $27.8 \pm 0.7^{\circ} \mathrm{C}(1 \sigma)$ around site 2404. This evidence indicates that SSTs from cores 2403, 2404, and A7 reflect the same season and depth as those at site $\mathrm{KY}$.

Temporal changes in SST and $\delta^{18} \mathrm{O}_{\mathrm{w}}$ at sites 2403, 2404, A7, and KY during the Holocene are shown in Fig. 7. Age models of these cores were established by ${ }^{14} \mathrm{C}$ of planktic foraminifers with high enough time resolution (every $\sim 1-$ $2 \mathrm{kyr}$ ) (Lin et al., 2006; Chen et al., 2010; Sun et al., 2005). The temporal changes in SSTs at sites 2403, 2404, and A7 show temperatures approximately $1-2{ }^{\circ} \mathrm{C}$ higher than that of site KY during the early Holocene, and keep these differences throughout the entire Holocene (Fig. 7a). An approximately $1-2{ }^{\circ} \mathrm{C}$ difference in SST between the southern ECS and northern ECS (KY) is also seen in modern SST distribution (Fig. 4). $\delta^{18} \mathrm{O}_{\mathrm{w}}$ from cores 2403,2404 , and $\mathrm{A} 7$ averaged over the late Holocene (2-0 kyr BP) also shows values approximately $0.2 \%$ o higher than those at site KY (Fig. 7b). The $0.2 \%$ higher value in $\delta^{18} \mathrm{O}_{\mathrm{w}}$ corresponds to a value 1 higher on the salinity scale at present $(0.2 \%$ o 1 ; Oba, 1990). Although a difference of 1 is approximately 0.5 larger than the value expected from modern distribution of salinity during summer (Fig. 4), a $0.5(0.1 \%$ ) difference is within the error of $\delta^{18} \mathrm{O}_{\mathrm{w}}$ propagated from $\mathrm{Mg} / \mathrm{Ca}$ SST and $\delta^{18} \mathrm{O}_{\mathrm{c}}$. An approximately $0.4 \%$ o decreasing trend from the early to middle Holocene in all of the $\delta^{18} \mathrm{O}_{\mathrm{w}}$ records at sites 2403, 2404, and A7 is mostly attributed to the decrease in the continental ice volume.

According to Zhang et al. (2007), any of the SSTs and $\delta^{18} \mathrm{O}_{\mathrm{w}}$ at sites 2403, 2404, and A7 could be used as the KSW end member values based on comparison with the modern spatial pattern in SST and salinity. However, on the millennial scale, the timing and amplitude of $\delta^{18} \mathrm{O}_{\mathrm{w}}$ changes at these three sites do not seem to be similar even if the age uncertainties are taken into consideration. This is possibly due to either the combination of analytical errors, an error in $\delta^{18} \mathrm{O}_{\mathrm{w}}$ attributable to heterogeneity of the samples, or local variability of precipitation/evaporation. In order to obtain the end member $\delta^{18} \mathrm{O}_{\mathrm{w}}$ of the KSW and its temporal changes, the original $\delta^{18} \mathrm{O}_{\mathrm{w}}$ data from sites 2404, 2403, and $\mathrm{A} 7$ are resampled every $0.01 \mathrm{kyr}$ using the software "Analy-

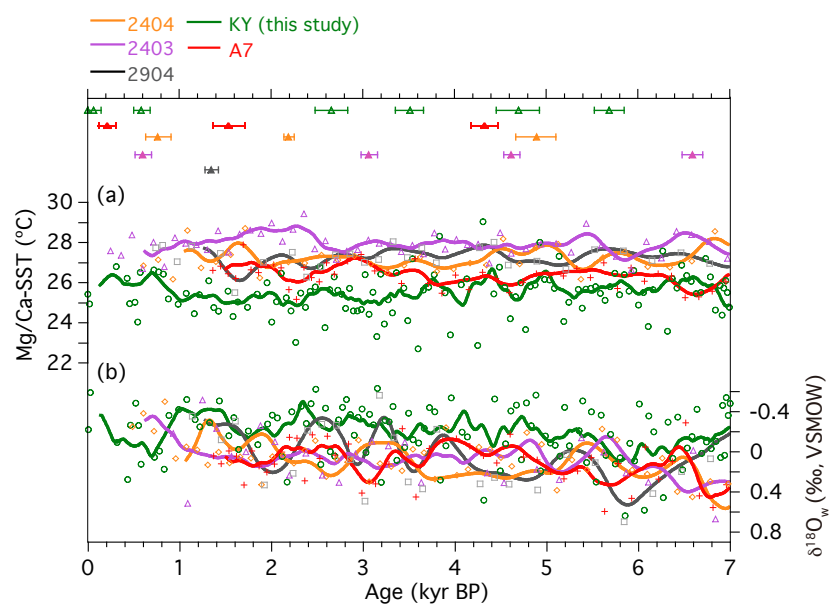

Figure 7. Diagrams show temporal changes in (a) $\mathrm{Mg} / \mathrm{Ca}$-derived $\mathrm{SST}$ and (b) $\delta^{18} \mathrm{O}_{\mathrm{w}}$ during the last $7 \mathrm{kyr}$. Gray, purple, orange, red, and green lines represent 300-year average for 2904 (Steinke et al., 2011), 2403 (Lin et al., 2006), 2404 (Chen et al., 2010), A7 (Sun et al., 2005), and KY (this study), respectively. Original data are shown in the same colors for each core. Triangles and bars indicate age control points and errors of $2 \sigma$.

Series" (http://www.lsce.ipsl.fr/logiciels/index.php) and presented as a 300-year moving averaged record (Fig. 7). The 300 -year averaging seems reasonable, as maximum age uncertainty for these data sets is about 300 years. The difference between calculated $\delta^{18} \mathrm{O}_{\mathrm{KSW}}$ and individual 300-yearaveraged $\delta^{18} \mathrm{O}_{2404}, \delta^{18} \mathrm{O}_{2403}$, and $\delta^{18} \mathrm{O}_{\mathrm{A} 7}$ at the same age does not exceed $\pm 0.26 \%$. Thus, we estimate the uncertainty of $\delta^{18} \mathrm{O}_{\mathrm{KSW}}\left(\varepsilon_{\mathrm{KSW}}\right)$, which is due mostly to spatial heterogeneity and age uncertainty, to be $\pm 0.26 \%$ o. Since $\delta^{18} \mathrm{O}_{\mathrm{w}}$ data for KSSW during the last $7 \mathrm{kyr}$ are not currently available, the end member $\delta^{18} \mathrm{O}_{\mathrm{w}}$ of the KSSW was produced hypothetically by adding $0.05 \%$ to $\delta^{18} \mathrm{O}_{\mathrm{w}}$ of the KSW, which is the difference between $\delta^{18} \mathrm{O}_{\mathrm{w}}$ of the KSSW and KSW observed at present (Table 1). We assume that the difference in $\delta^{18} \mathrm{O}_{\mathrm{w}}$ between the KSW and KSSW has been kept small $(<0.1 \%$ ) during the Holocene because of the following reasons: In modern conditions, the difference in $\delta^{18} \mathrm{O}_{\mathrm{w}}$ between the KSW and KSSW is estimated as being $<0.1 \%$ o from the salinity difference of $<0.5$ (using data from JODC available at http://jdoss1.jodc.go.jp/cgi-bin/1997/bss.jp) during June to August (the most stratified season), and $\delta^{18} \mathrm{O}_{\mathrm{KSW}}$ is lower than $\delta^{18} \mathrm{O}_{\mathrm{KSSW}}$ owing to excess precipitation over evaporation at the surface. Interannual salinity variability is larger (standard deviation: $\pm 0.06 \%$ ) at the surface compared to at a depth of $\sim 100 \mathrm{~m}$, and the latter is more stable within $\pm 0.018 \%$ o (JODC). The surface freshening is the main factor that controls the salinity (and $\delta^{18} \mathrm{O}_{\mathrm{w}}$ ) difference between the surface and subsurface water, and therefore it is reasonable to consider that $\delta^{18} \mathrm{O}_{\mathrm{KSW}}$ has always been lower than $\delta^{18} \mathrm{O}_{\mathrm{KSSW}}$. As to the maximum offset during the last $7 \mathrm{kyr}$, considering that vertical mixing due to 
the winter monsoon wind is the major factor reducing the offset, and the intensity of the winter monsoon wind over the East China Sea is expected to have been stronger during the middle Holocene based on a multi-model analysis (Zhao and Harrison, 2011), it would be reasonable to assume that the offset has never been larger than $0.1 \%$. Therefore, the minimum and maximum offsets between $\delta^{18} \mathrm{O}_{\mathrm{KSW}}$ and $\delta^{18} \mathrm{O}_{\mathrm{KSSW}}$ are assumed to be 0 and $0.1 \%$, respectively, namely $\delta^{18} \mathrm{O}_{\mathrm{KSSW}}=\delta^{18} \mathrm{O}_{\mathrm{KSW}} 0.05( \pm 0.05)$.

SST and $\delta^{18} \mathrm{O}_{\mathrm{w}}$ data in the northern South China Sea (MD05-2904, hereafter 2904; $19^{\circ} 27.32 \mathrm{~N}, 116^{\circ} 15.15 \mathrm{E}$; water depth of $2066 \mathrm{~m}$; Steinke et al., 2011) during the Holocene, which was also derived from paired measurement of $\mathrm{Mg} / \mathrm{Ca}$ and $\delta^{18} \mathrm{O}$ of G. ruber, are available as TSW end member values (Fig. 7). The 2904 data set was calculated using the same equations used for core $\mathrm{KY}$ and other three sites in the ECS. Site 2904 is situated in the northern South China Sea, relatively close to the Taiwan Strait. G. ruber is also abundant during warmer months in the South China Sea (Lin et al., 2004). The core top $\mathrm{Mg} / \mathrm{Ca}$ SST at site 2904 in the northern South China Sea is $27.8^{\circ} \mathrm{C}$ (Steinke et al., 2011), which is $0.6^{\circ} \mathrm{C}$ cooler than the modern average SST $\left(28.4^{\circ} \mathrm{C}\right)$ from June to October. Although there are no $\delta^{18} \mathrm{O}_{\mathrm{w}}$ data for the 2904 core top, average $\delta^{18} \mathrm{O}_{\mathrm{w}}$ for the last $2 \mathrm{kyr}(-0.12 \%)$ is comparable to the modern TSW end member considering variability in $\delta^{18} \mathrm{O}_{\mathrm{w}}$ (standard deviation $=0.26 \%$ ) record for core 2904 during the last $2 \mathrm{kyr}$.

An age model of core 2904 for the Holocene was established based on three control points of calibrated ${ }^{14} \mathrm{C}$ datum at 15.6, 7.5, and 1.4 kyr BP (Ge et al., 2010). The original SST and $\delta^{18} \mathrm{O}_{\mathrm{w}}$ data were resampled and averaged in the same manner as the other core records. A temporal high peak in $\delta^{18} \mathrm{O}_{\mathrm{w}}$ record of 2904 at $\sim 6 \mathrm{kyr}$ BP corresponds to high $\delta^{18} \mathrm{O}_{\mathrm{w}}$ values in $\mathrm{KY}$ record around $6 \mathrm{kyr} \mathrm{BP}$, suggesting that the change in $\delta^{18} \mathrm{O}_{\mathrm{w}}$ of the TWS end member might have had an influence on $\delta^{18} \mathrm{O}_{\mathrm{w}}$ of site $\mathrm{KY}$ at least in part.

Eventually, the temporal variations in end member $\delta^{18} \mathrm{O}_{\mathrm{w}}$ of KTW,

$\delta^{18} \mathrm{O}_{\mathrm{KTW}}=1 / 2 E \delta^{18} \mathrm{O}_{\mathrm{TSW}}=1 / 4 E\left(2 \delta^{18} \mathrm{O}_{\mathrm{KSW}}+0.05\right)$,

were obtained with the $\delta^{18} \mathrm{O}_{\mathrm{w}}$ of 2904,2403 , 2404, and A7 according to the fixed proportions of $Q_{\mathrm{TSW}_{(2904)}}=2 Q_{\mathrm{KSW}_{(2403,2404, \mathrm{~A} 7)}}=2 Q_{\mathrm{KSSW}}$ (Fig. 8). We assume that this proportion has been maintained since $7 \mathrm{kyr} \mathrm{BP}$, when the sea level reached approximately the modern level, as the flow rate in the Taiwan Strait should be significantly affected by lowering of the sea level due to its shallow sill depth. A propagated error of $\delta^{18} \mathrm{O}_{\mathrm{KTW}}\left(\varepsilon_{\mathrm{KTW}}\right)$ in Eq. (6) is expressed as follows:

$\varepsilon_{\mathrm{KTW}}\left(1 / 2 E \varepsilon_{\mathrm{TSW}}+1 / 2 E \varepsilon_{\mathrm{KSW}}+1 / 4 E \varepsilon_{\mathrm{KSSW}}\right)$.

As $\delta^{18} \mathrm{O}_{\mathrm{w}}$ of core 2904 is the TSW end member, the value of $\pm 0.12 \%$ o that stems from the $\mathrm{Mg} / \mathrm{Ca}$ and $\delta^{18} \mathrm{O}$ measurements can be applied as the error of $\delta^{18} \mathrm{O}_{\mathrm{TSW}}$.

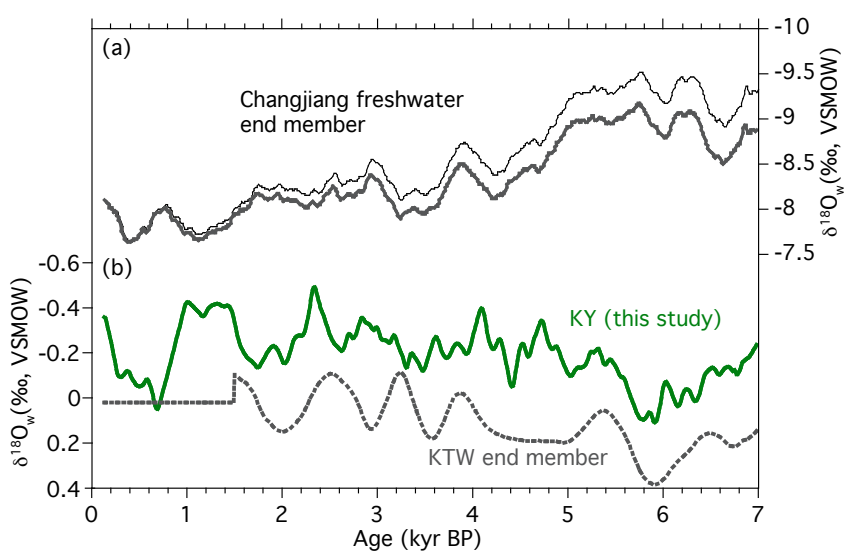

Figure 8. (a) $\delta^{18} \mathrm{O}_{\mathrm{w}}$ of the Changiiang freshwater end member calculated from a speleothem in Heshang Cave in China (Hu et al., 2008). (b) $\delta^{18} \mathrm{O}_{\mathrm{w}}$ of marine cores in the northern ECS (KY07-0401, in green) and end member of Kuroshio Taiwan Water (KTW, gray dotted line).

When $\varepsilon_{\mathrm{TSW}}=0.12 \%, \varepsilon_{\mathrm{KSW}}=0.26 \%$, and $\varepsilon_{\mathrm{KSSW}}=0.05$, $\varepsilon_{\mathrm{KTW}}$ is calculated to be $0.20 \%$. On the other hand, the error stemming from changes in the mixing ratio of the water masses should be smaller than $0.26 \%$, because the differences among the calculated values of $\delta^{18} \mathrm{O}_{\mathrm{KTW}}$, $\delta^{18} \mathrm{O}_{\mathrm{TSW}}, \delta^{18} \mathrm{O}_{\mathrm{KTW}}$, and $\delta^{18} \mathrm{O}_{\mathrm{KSSW}}$ are small, and this is explained as follows. The difference between $\delta^{18} \mathrm{O}_{\mathrm{KTW}}$ and $\delta^{18} \mathrm{O}_{\mathrm{KSW}}\left(\delta^{18} \mathrm{O}_{\mathrm{KSSW}}\right)$ in the same time slice is always within $\pm 0.26 \%$. Similarly, the difference between $\delta^{18} \mathrm{O}_{\mathrm{KTW}}$ and $\delta^{18} \mathrm{O}_{\mathrm{TSW}}$ in the same time slice is within $\pm 0.26 \%$ o, except for the time interval between 7 and $6.8 \mathrm{kyr} \mathrm{BP}$, when the difference between them is about $0.3 \%$. Here, the value of $\delta^{18} \mathrm{O}_{\mathrm{KTW}}$ is determined depending on the amount each water mass contributes. At 7-6.8 kyr BP, the differences would be within $\pm 0.26 \%$ if the contribution of TSW on KTW could be considered to be less than $90 \%$. Considering the modern mixing ratio of the water masses described in the above equation, a contribution from TSW of $90 \%$ seems unlikely. Therefore, the error stemming from changes in the mixing ratio of the water masses can be considered to be within $\pm 0.26 \%$, and the possible maximum error of $\delta^{18} \mathrm{O}_{\mathrm{KTW}}$ is $\pm 0.26 \%$. A fixed $\delta^{18} \mathrm{O}_{\mathrm{KTW}}$ value of $0.028 \%$ is tentatively proposed for the last $1.5 \mathrm{kyr}$ because of the lack of available data in this interval for A7, 2404, and 2904.

\subsubsection{Reconstruction of temporal changes in $\delta^{18} \mathrm{O}_{\mathrm{W}}$ of the freshwater end member}

To obtain the time-series data set of the end member $\delta^{18} \mathrm{O}_{\mathrm{CFW}}$ for the Holocene, we utilized the Chinese speleothem $\delta^{18} \mathrm{O}$ to derive the $\delta^{18} \mathrm{O}$ of the freshwater; these data can be calculated using the calcite equilibrium equation of O'Neil et al. (1969) (expressed as Eq. 1). For the Holocene, four data sets of speleothem $\delta^{18} \mathrm{O}$ from three caves are currently available in or near the Changjiang Basin. 
Among these data, we choose the speleothem $\delta^{18} \mathrm{O}$ from Heshang Cave, which is located in Qingjiang Valley, in the middle reaches of the Changjiang $\left(30^{\circ} 27^{\prime} \mathrm{N}, 110^{\circ} 25^{\prime} \mathrm{E} ; 294 \mathrm{~m}\right.$ elevation). As the summer monsoon with its abundant precipitation results in isotopic signatures that are closer to the values typically observed in summer precipitation of the lower and middle reaches (Müller et al., 2012), precipitation $\delta^{18} \mathrm{O}$ at Heshang Cave can be regarded as reflecting the average value of the precipitation $\delta^{18} \mathrm{O}$ within the catchment of the Changjiang. The geological and climatological settings around this cave are well studied, and drip-water $\delta^{18} \mathrm{O}$ in this cave responds rapidly (lag of less than 1 month) to changes in rainfall $\delta^{18} \mathrm{O}$ (Johnson et al., 2006). The mean annual precipitation is $1460 \mathrm{~mm}$, with approximately $80 \%$ of the annual rainfall occurring during the summer monsoon months of June-August (Johnson et al., 2006). Since the summer precipitation amount accounts for $80 \%$ of the annual total precipitation, amount-weighted annual mean dripwater $\delta^{18} \mathrm{O}(-7.4 \%$ ) at this cave site (Johnson et al., 2006) shows a value similar to the average $\delta^{18} \mathrm{O}$ of rainfall from June to August: $-7.8 \%$. Also, the drip-water $\delta^{18} \mathrm{O}(-7.4 \%$ ) is close to modern wet season (May to October) $\delta^{18} \mathrm{O}_{\mathrm{CFW}}$ at the Changjiang river mouth ( -7.4 to $-5.8 \%$; Zhang et al., 1990). This is because contribution of the heavy $\delta^{18} \mathrm{O}$ of the rainfall in other months $(-5.5 \%$ on average) (November to April) to the annual rainfall $\delta^{18} \mathrm{O}$ is very small. Because the recharge of the water into this cave is rapid and humidity of the cave is higher than $95 \%$ throughout the year, evaporation does not alter the $\delta^{18} \mathrm{O}$ of rainfall before it precipitates as speleothems in the modern setting (Hu et al., 2008). Moreover, the speleothem calcites in this cave are considered to have been precipitated under equilibrium conditions as the signature of the kinetic effect is lacking (Hu et al., 2008).

Because the speleothem in this cave provides a continuous speleothem $\delta^{18} \mathrm{O}$ record since $9.5 \mathrm{kyrBP}$ (Hu et al., 2008), temporal changes in $\delta^{18} \mathrm{O}$ of drip water can be calculated if the cave temperature is known. Johnson et al. (2006) reported the modern annual average cave temperature of $17.1^{\circ} \mathrm{C}$. On the other hand, Shi et al. (1993) claimed that deviations of the annual temperature from present-day values during the middle Holocene were $+2{ }^{\circ} \mathrm{C}$ in the Changjiang Basin based mainly on pollen analyses. Since the annual surface air temperature is considered to have reached its maximum during the middle Holocene (Shi et al., 1993), a $+2{ }^{\circ} \mathrm{C}$ change would be the maximum estimate for the cave temperature change throughout the Holocene. Although a $+2{ }^{\circ} \mathrm{C}$ increase in cave temperature leads to a $\sim 0.5 \%$ increase in the estimate of drip-water $\delta^{18} \mathrm{O}$, the impact of a temperature change of this magnitude on the estimate of $f_{\mathrm{CFW}}$ was less than $0.15 \%$ and hence very small. Assuming that the cave temperature has been constant at $17.1^{\circ} \mathrm{C}$ through the last $7 \mathrm{kyr}$, temporal changes in $\delta^{18} \mathrm{O}$ of the drip water, which is assumed to have been equal to $\delta^{18} \mathrm{O}$ of the rainfall that mainly reflects the summer season, are obtained (Fig. 8). The $\delta^{18} \mathrm{O}_{\mathrm{CFW}}$ shows a distinct long-term increasing trend $(1.5 \%$ )
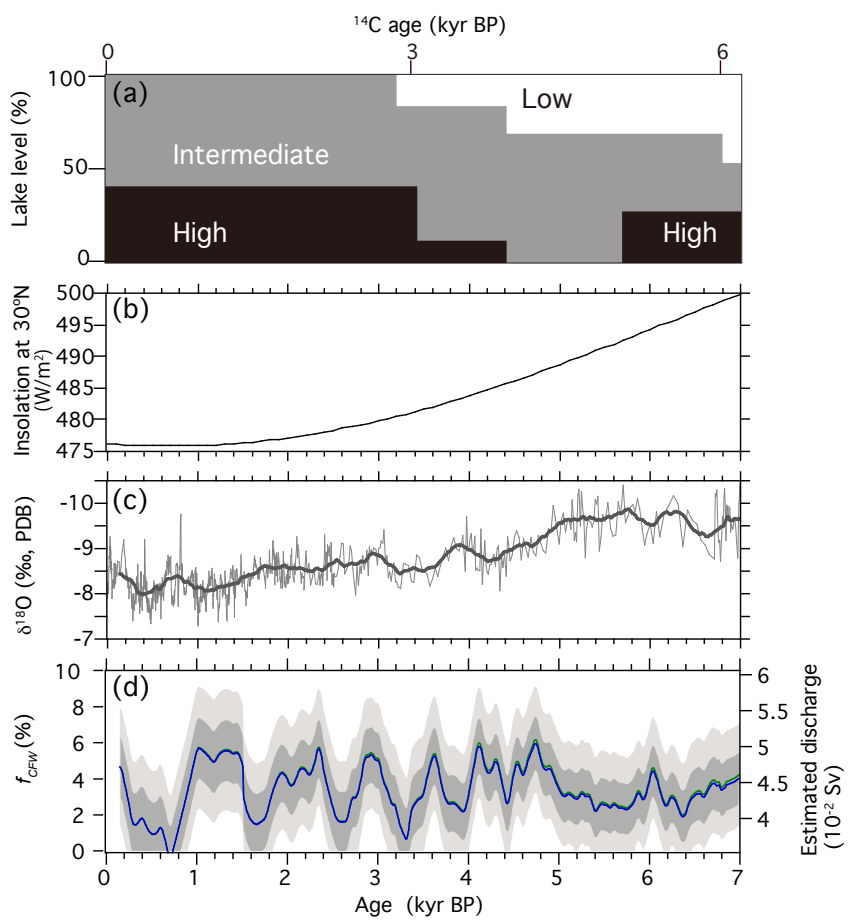

Figure 9. (a) The regional lake-level record in the Changjiang Basin compiled by An et al. (2000). (b) Insolation on June 21 at $30^{\circ} \mathrm{N}$ (Lasker et al., 2004). (c) Speleothem $\delta^{18} \mathrm{O}$ in Heshang Cave (Hu et al., 2008). (d) Relative contribution of the Changjiang freshwater ( $\left.f_{\mathrm{CFW}}\right)$ at site $\mathrm{KY}$ in the northern East China Sea and estimated Changjiang freshwater discharge. Light- and dark-gray shaded areas indicate uncertainties with propagated errors of $0.5 \sigma$ and $1 \sigma$, respectively. The green and blue lines respectively indicate estimated $f_{\mathrm{CFW}}$ with a $2^{\circ} \mathrm{C}$ temperature gradient occurring since the middle Holocene and with a constant cave temperature of $17.1^{\circ} \mathrm{C}$.

since $\sim 5 \mathrm{kyr}$ BP, whereas millennial-scale variations are less prominent. Another speleothem record from Sanbao Cave $\left(110^{\circ} 26^{\prime} \mathrm{E}, 31^{\circ} 40^{\prime} \mathrm{N} ; 1900 \mathrm{~m}\right.$ above sea level) and Dongge Cave $\left(25^{\circ} 17^{\prime} \mathrm{N}, 108^{\circ} 05^{\prime} \mathrm{E} ; 680 \mathrm{~m}\right.$ above sea level) also has a long-term increasing trend from the middle to late Holocene with a magnitude of approximately $-1.5 \%$, which is similar to that of the Heshang record. However, their absolute values are different from the Heshang record due to the altitude or continental effect combined with temperature difference in calcite precipitation (Dansgaard, 1964). The increasing trend of $1.5 \%$ in drip-water $\delta^{18} \mathrm{O}$ or a $1.0 \%$ increase in drip-water $\delta^{18} \mathrm{O}$ with a $+2{ }^{\circ} \mathrm{C}$ temperature increase is a robust feature in the Changjiang Basin.

\subsubsection{Reconstructed contribution of the Changjiang freshwater}

The $f_{\text {CFW }}$, which was calculated using Eqs. (4) and (5), has varied between 5 and $0 \%$ on submillennial to millennial scale since $7 \mathrm{kyr}$ BP (Fig. 9). A propagated error for $f_{\mathrm{CFW}}$ is calculated using values of $0.26 \%$ for $\delta^{18} \mathrm{O}_{\mathrm{KTW}}, 0.12 \%$ o 
for $\delta^{18} \mathrm{O}_{\mathrm{KY}}$, and $0.46 \%$ for $\delta^{18} \mathrm{O}_{\mathrm{CFW}}$, and is derived from the estimate of the $\pm 2{ }^{\circ} \mathrm{C}$ error in air temperature.

The decreasing trend from the middle to late Holocene, which is a characteristic feature of the Chinese speleothem $\delta^{18} \mathrm{O}$ records, is absent in our $f_{\mathrm{CFW}}$ record. As to submillennial- to millennial-scale variations, higher $f_{\mathrm{CFW}}$ values are recognized at 4.7, 4.1, 3.6, 2.9, 2.3, and 1.5$1.0 \mathrm{kyr} \mathrm{BP}$, while lower $f_{\mathrm{CFW}}$ values are recognized at 6.3 , 5.8-5.4, 4.4, 3.9, 3.3, 2.6, 1.6, and 0.7 kyr BP. Although amplitude of the centennial- to millennial-scale variations in the speleothem $\delta^{18} \mathrm{O}$ is approximately $1 \%$ at the maximum, a $1 \%$ difference in the end member $\delta^{18} \mathrm{O}_{\mathrm{CFW}}$ leads to only a $0.3 \%$ difference in $f_{\mathrm{CFW}}$. Thus short-term changes in the end member $\delta^{18} \mathrm{O}_{\mathrm{CFW}}$ do not alter the reconstructed results of $f_{\text {CFW }}$. Fig. 9 shows the result of $f_{\text {CFW }}$ calculated by assuming a monotonous decrease in air temperature of $2^{\circ} \mathrm{C}$ since $7 \mathrm{kyr} \mathrm{BP}$, together with a case in which $f_{\mathrm{CFW}}$ is calculated at the fixed cave temperature $\left(17.1^{\circ} \mathrm{C}\right)$. The result indicates no prominent long-term trend from the middle Holocene, suggesting that the cause of the absence of a long-term trend in $\delta^{18} \mathrm{O}_{\mathrm{w}}$ at the $\mathrm{KY}$ site is not related to changes in the end member $\delta^{18} \mathrm{O}_{\mathrm{CFW}}$ but to the absence of a long-term trend in the Changjiang freshwater flux.

\subsection{Flux estimation of the Changjiang freshwater}

In order to estimate the past flux of the Changjiang freshwater $\left(Q_{\mathrm{CFW}}\right)$ into the ECS, the modern relationship between $Q_{\mathrm{CFW}}$ and $f_{\mathrm{CFW}}$ at site $\mathrm{KY}$ was examined. Subsequently, the past $Q_{\mathrm{CFW}}$ during the Holocene was estimated by applying the modern $Q_{\text {CFW }}$ versus $f_{\text {CFW }}$ relationship at the core site. Reconstruction of the absolute salinity value is not necessary when applying this method, and this method allows one to avoid introducing additional errors caused by the process of salinity reconstruction. The modern $f_{\mathrm{CFW}}$ at site $\mathrm{KY}$ can be estimated by using the observational salinity data and water mass-balance calculations described in Eqs. (6) and (7).

The modern $f_{\mathrm{CFW}}$ at site $\mathrm{KY}$ can be estimated by using the observational salinity data and water mass-balance calculation described in Eqs. (6) and (7).

$$
\begin{aligned}
& S_{\mathrm{KTW}} \cdot Q_{\mathrm{KTW}}=S_{\mathrm{KY}}\left(Q_{\mathrm{CFW}}+Q_{\mathrm{KTW}}\right) \\
& Q_{\mathrm{CFW}} / Q_{\mathrm{KTW}}=f_{\mathrm{CFW}} / f_{\mathrm{KTW}}
\end{aligned}
$$

First, for $Q_{\mathrm{CFW}}$, modern observational data of the Changjiang freshwater discharge at Datong hydrological station during the wet season (May-October) were collected for 50 years, from 1951 to 2000 (Fang et al., 2011). Here, $S$ was defined as the salinity averaged from June through October, taking into consideration of a 1-month lag in arrival of the Changjiang freshwater at site KY. For $S_{\mathrm{KY}}$, the original data set of the salinity around site KY (within a $1^{\circ}$ grid box of $30-31^{\circ} \mathrm{N}$ and $127-128^{\circ} \mathrm{E}$ ), which was obtained by the Nansen bottle water sampler and mechanical bathythermographs (MBT), expendable bathythermographs (XBT), and conductivity-temperature-depth profilers (CTD), from 1951 to 2000, was downloaded from an online archive (JODC). The original salinity data at a water depth of 0 to $30 \mathrm{~m}$ were averaged from July through August for each year, because the salinity data were not continuous in other months and were biased towards July and August. Furthermore, salinity data do not exist for the years 1957 and 1961 in the JODC archive. In addition, the salinity averaged from June through October is 0.25 higher than the July-August salinity based on the monthly averaged salinity data (JODC), and therefore 0.25 is added to the July-August data set for each year.

As to $S_{\mathrm{KTW}}$, salinity observation has been sparse both in the Taiwan Strait and the southern ECS in the last 50 years. Therefore, a fixed value of 34.38 for $S_{\mathrm{KTW}}$ was tentatively applied. This value is considered to be acceptable, because according to standard deviations of surface salinity data, interannual changes in salinity are small in the Taiwan Strait (Kalnay et al., 1996) and the southern ECS (JODC).

The interannual correlation between the Changjiang discharge and $f_{\text {CFW }}$ was poor $\left(R^{2}=0.16\right.$, not shown), probably due to the $\sim 2-3$-year residence time for the waters in the East China Sea (Nozaki et al., 1991). By contrast, a strong correlation between 5-year-mean $S_{\mathrm{KY}}$ and $f_{\mathrm{CFW}}$ was found (Fig. 10a and b). This is reasonable considering that a flood-drought cycle for the Changjiang shows 5.09-year cyclicity (Jiang et al., 2006). The 5-year-mean salinity data for period 1986-1990 was deviated from the regression line and shows lower values than that was expected from the Changjiang discharge during this period (Fig. 10). The lowering of the salinity in this period might be attributed to (1) the increase in precipitation around the core site or (2) the decrease in salinity in the Kuroshio Waters and/or TSW. Based on the examination of the observational salinity data within a grid of $24-25^{\circ} \mathrm{N}, 122-123^{\circ} \mathrm{E}$ downloaded from JODC data archive, salinity for the Kuroshio Water in 1989-1990 showed -0.3 deviations from the average value. Therefore, it is likely that the exceptionally low salinity at site $\mathrm{KY}$ is attributed to the decrease in salinity of the KTW end member. Since the $\delta^{18} \mathrm{O}_{\mathrm{w}}$ of the KTW end member is controlled by local precipitation-evaporation balance, the lower salinity might be due to higher precipitation in the Kuroshio water area. The data for period 1996-2000 are omitted due to a larger annual variability $\left(\sigma^{2}=1.72\right)$ than other periods $\left(\sigma^{2}=0.1-0.2\right)$, although they were in good agreement with a regression line. With the data for the periods 19861990 and 1996-2000 omitted, a clear positive relationship $\left(R^{2}=0.95\right)$ between $Q_{\mathrm{CFW}}$ and $f_{\mathrm{CFW}}$ was obtained (Line 1: $\left.Q_{\text {CFW }}\left(\times 10^{-2} \mathrm{~Sv}\right)=0.25 f_{\mathrm{CFW}}(\%)+3.52\right)$. Even if the data during 1986-1990 are included, a robust relationship still exists $\left(R^{2}=0.58\right)$, but the slope of the regression line becomes smaller (Line 2: $\left.Q_{\mathrm{CFW}}\left(\times 10^{-2} \mathrm{~Sv}\right)=0.21 f_{\mathrm{CFW}}(\%)+3.54\right)$. The $y$ intercept of the regression lines is not zero but points to $3.5\left(\times 10^{-2} \mathrm{~Sv}\right)$, suggesting that the discharge cannot be detected at this core site when the Changiiang discharge in the wet season is lower than $3.5 \times 10^{-2} \mathrm{~Sv}$. Although the sensitivity of salinity to the variations in the Changjiang freshwa- 
ter influx is relatively low in the northeastern end of the ECS, the influence of the Changjiang freshwater discharge is detectable at site KY. Simulations with a numerical model show that the southerly wind, which is predominant in the summer season, enhances the eastward extension of the CDW, suggesting the importance of the monsoonal wind effect on the behavior of the CDW (Lie et al., 2003). According to Jiang et al. (2008), the strength of the southerly wind has had a negative correlation with precipitation in the Changjiang Basin in the last $\sim 50$ years. That is, when the southerly wind is stronger, the Changjiang Basin receives less precipitation. Since the salinity around site KY has the robust negative correlation with the flux of the Changjiang, the influence of the strength of the southerly wind on SSS at site KY seems to be small.

The regression Line 1 was used for the calculation of the Holocene $Q_{\mathrm{CFW}}$ (Fig. 9). A calculation of $Q_{\mathrm{CFW}}$ by regression Line 2 gives the similar result (not shown) due to almost the same slope and $y$ intercept between the two lines. Average $Q_{\mathrm{CFW}}$ from the middle through late Holocene is $4.4 \times 10^{-2} \mathrm{~Sv}$, which is close to the modern average for $1951-2000\left(4.0 \times 10^{-2} \mathrm{~Sv}\right)$. The maximum and minimum of the reconstructed $Q_{\mathrm{CFW}}$ with Line 1 since $7 \mathrm{kyr} \mathrm{BP}$ are $5.1 \times 10^{-2} \mathrm{~Sv}$ (127\% of present-day average) and $3.4 \times 10^{-2} \mathrm{~Sv}$ ( $93 \%$ of present-day average), respectively. This range is smaller than interannual variability (2.8$\left.6.3 \times 10^{-2} \mathrm{~Sv}\right)$, but larger than decadal variability (3.6-4.6 $\times 10^{-2} \mathrm{~Sv}$ ) in the 50 years from 1951 to 2000 (Figs. 2 and 9).

\section{Discussion}

\subsection{Absence of decreasing trend and regional dissimilarity of the Holocene optimum precipitation}

The stronger boreal summer insolation in the Northern Hemisphere in the early/middle Holocene compared to today is believed to have increased EASM precipitation through the enhancement of the land-ocean thermal contrast (e.g., An et al., 2000). Simulation studies generally support this idea in areas under the influence of the Indian monsoon and South Asian monsoon (e.g., Liu et al., 2003; Kutzbach et al., 2008). However, a simulated precipitation result using a fully coupled ocean-atmosphere model depicts a different response of precipitation to the insolation change from region to region in the EASM areas. For example, the regions near the east coast of China in the Changiiang Basin receive less precipitation, while central, western, and southernmost China receives more precipitation during the early Holocene than today (Liu et al., 2003). A recent transient simulation study for the Holocene points out the complexity of the response of the Asian summer monsoon system to the Holocene insolation change (Jin et al., 2014). For example, the northern (northern China, southern Mongolia) and southern areas of the EASM
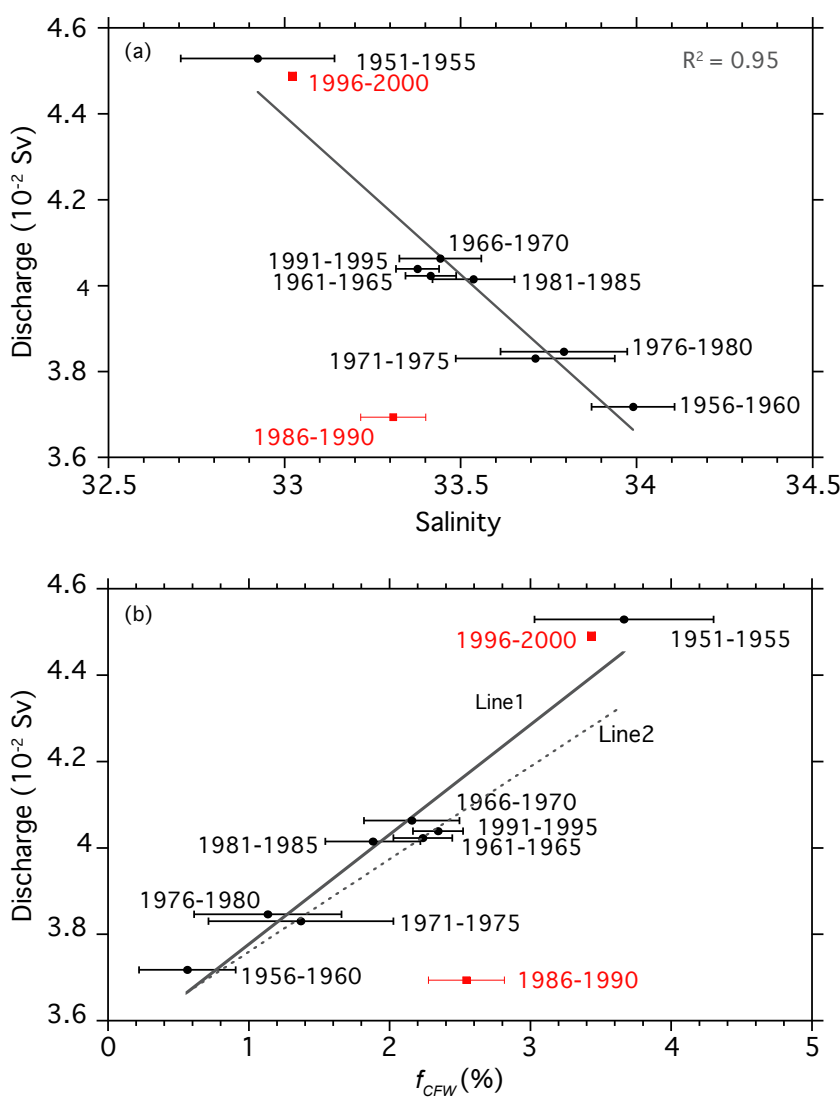

Figure 10. (a) Modern relationship between 5-year-mean salinity (July-August) around site KY and freshwater discharge of the Changjiang. Comparison of 5-year-mean wet season (MayOctober) Changjiang discharge at Datong station from 1951 to 2000, showing the robust relationship between them. Bars associated with black filled circles represent $\sigma^{2}$ of the annual mean for the 5-year interval. Original salinity data were collected with a Nansen bottle water sampler, and the MBT, CTD, and XBT measurements were downloaded for the area of $31^{\circ}-32^{\circ} \mathrm{N}, 128^{\circ}-129^{\circ} \mathrm{E}$ from an online archive (http://www.jodc.go.jp/jodcweb/JDOSS/index_j. $\mathrm{html}$ ). These salinity data were annually averaged from the depth of 0 to $30 \mathrm{~m}$, and further averaged every 5-year interval from 1951 to 2000. (b) Comparison of 5-year-mean wet season (May to October) Changjiang discharge at Datong station with 5-year-mean relative contribution of Changjiang freshwater $\left(f_{\mathrm{CFW}}\right)$ in the northern ECS derived from observational salinity data $\left(31^{\circ}-32^{\circ} \mathrm{N}, 128^{\circ}-129^{\circ} \mathrm{E}\right)$. The 5-year-mean data in the time interval from 1986 to 1990 and 1996-2000 are omitted (red squares).

(southwestern and southern China) have higher precipitation in the early to middle Holocene than today, while the central and eastern areas of the EASM (middle-lower reaches of the Changjiang Basin, Korea, and Japan) have less precipitation. Thus, a different precipitation response to the insolation change could be the one of the features of the EASM. Jin et al. (2014) explains that this dissimilarity is attributed to internal feedbacks within climate system, such as the air-sea in- 
teractions associated with the El Niño-Southern Oscillation (ENSO) and shift of the Intertropical Convergence Zone.

The reconstructed Changjiang freshwater flux in this study shows that there has been no long-term decreasing trend from the middle Holocene that is instead apparent in the Chinese speleothem $\delta^{18} \mathrm{O}$ (e.g., Wang et al., 2005). On the other hand, An et al. (2000) argued that the temporal-spatial pattern of the EASM precipitation was asynchronous across China and it could be explained by the southward retreat of the monsoon front during the Holocene. Their study also inferred that the EASM precipitation peak in the middle and lower reaches of the Changjiang occurred at $8-5 \mathrm{kyr} B \mathrm{P}$, based on a climate model simulation, pollen counts, and lake-level records. However, the high precipitation peak that is expected at 8$5 \mathrm{kyr}$ BP is not evident in the compiled lake-level records in the middle and lower reaches of the Changjiang, and the lake levels seem to have increased slightly from the middle Holocene (An et al., 2000). Therefore, at least, neither our Changjiang flux record nor the compiled lake-level record supports the view that the EASM precipitation has reduced since the middle Holocene. Moreover, the lack of a decreasing trend in both our Changjiang flux records and the compiled lake-level records from the middle and lower reaches of the Changjiang by An et al. (2000) further suggests that the regional summer precipitation intensity is not the main controlling factor of the Chinese speleothem $\delta^{18} \mathrm{O}$. As is suggested by other authors, the changes in winter temperature (Clemens et al., 2010) or variations in synoptic circulation patterns (Tan, 2007; Maher, 2008; Maher and Thompson, 2012) could produce the gradual increasing secular trend in the Chinese speleothem $\delta^{18}$ O. Maher and Thompson (2012) examined the possible factors that control the orbital-scale variations in the Chinese speleothem $\delta^{18} \mathrm{O}$, and concluded that changes in the moisture source are most likely. They argued that the moisture contribution has shifted from more Indian Ocean source (less Pacific source) to less Indian Ocean source (more Pacific source) from the middle Holocene, which is attributed to the changes in the atmospheric circulation pattern driven by precessional forcing. However, there is a small discrepancy between our Changjiang flux record and the compiled regional lake-level record - that is, our Changjiang flux record does not have an increasing trend from the middle Holocene, which is suggested by the compiled regional lake-level record. A possible explanation for this discrepancy is that the number of the lake-level records that were used for the compilation by An et al. (2000) may not be enough to capture the average of the precipitationevaporation balance over the entire Changjiang Basin and part of the lake-level record may reflect local effect such as changes in hydrological connection with local rivers or the impact of human activities.

On the other hand, there is evidence that suggests a decline in EASM precipitation from the early/middle Holocene to the present day in northern China based on the compiled lake-level record (An et al., 2000) and oxygen and carbon isotopes from lake sediments and peat bogs (Zhang et al., 2011). However, there is heterogeneity of the temporal precipitation pattern even in northern China during the Holocene. For example, a reconstruction of paleo-rainfall using a loess/paleosol sequence at Duowa, at the north-western margin of the present-day summer monsoon limit, based on a magnetic climofunction, suggests the enhancement in EASM precipitation from the middle Holocene to the present (Maher and $\mathrm{Hu}, 2006)$.

Thus, the spatially heterogeneous precipitation pattern over China is an important characteristic during the Holocene. Furthermore, the insolation does not regulate the regional EASM precipitation over the Changjiang Basin during the Holocene, and instead the internal feedback seems to be a more important mechanism. However, this might be the case only for specific periods, such as the Holocene, when the amplitude of the insolation forcing is below a threshold and not enough to regulate the EASM precipitation (Nakagawa et al., 2008). The precession cycle (19-23 kyr) is predominantly found in the quantitative summer precipitation record from Lake Biwa, central Japan, based on a pollen record for the last $400 \mathrm{kyr}$, with some exceptions during marine isotope stage (MIS) 1-3 and 10-12, when the eccentricity values were below 0.024 (Nakagawa et al., 2008). During these eccentricity minima periods, the insolation control over the EASM decreased in importance relative to the internal feedback mechanism and/or the glacial-interglacial global climate background change (Nakagawa et al., 2008).

\subsection{Millennial-scale variations in Changjiang freshwater discharge since $7 \mathrm{kyr} B P$}

Although there is uncertainty in the reconstructed Changjiang freshwater discharge, submillennial- to millennial-scale variability is marginally visible. The reconstructed freshwater flux since $7 \mathrm{kyr}$ BP shows that the maximum discharge was $4.9 \times 10^{-2} \mathrm{~Sv}$ around $4.7 \mathrm{kyr} \mathrm{BP}$.

The increase of $0.9 \times 10^{-2} \mathrm{~Sv}$ relative to the mean value of $4.0 \times 10^{-2} \mathrm{~Sv}$ for the period from 1951 to 2000 is equivalent to the 39 occurrences of high discharge in the 1954 case $\left(6.3 \times 10^{-2} \mathrm{~Sv}\right)$ per 300 years if all of the increase in the discharge is attributed to extremely high discharge events. That is, it is 13 times per 100 years, which is $\sim 4$ times higher than the last 100 years, where extreme high discharge events exceeding $2 \sigma\left(>5.3 \times 10^{-2} \mathrm{~Sv}\right)$ occurred 3 times.

In modern climatology, a linkage of the floods/droughts with ENSO has been investigated in the EASM-dominated region (e.g., Chang and King, 1994; Dilley and Heyman, 1995; Lan et al., 2003; Zhang et al., 2006). The most pronounced low-level anomalous anticyclone over the western North Pacific, persisting from the El Niño mature winter to the subsequent summer, plays a crucial role in the El NiñoEASM teleconnection (Wang et al., 2000, 2008; Chang et al., 2000; Zhou et al., 2009). As to the Yellow River (northern China), a high probability of low discharge follows the 
occurrence of El Niño, while flood events follow the occurrences of La Niña (Lan et al., 2002). The teleconnections between flood/drought events and ENSO were also investigated in the Changjiang (Jiang et al., 2006; Zhang, Q. et al., 2006; Zhang, L. et al., 2007). In short, in the decaying phase of El Niño, the precipitation anomaly in the following summer exhibits a "southern (Changiiang) flood and northern (Yellow River) drought" pattern over eastern China (Huang and Huang, 2012). When El Niño occurs, the rainfall intensifies in subsequent summer along the Changjiang Basin in accordance with the southwestward displacement of the western North Pacific subtropical high (Liu et al., 2008). The seasonal march of the monsoon front from south to north is one of the prominent features of the EASM. The rainy season starts at $20^{\circ} \mathrm{N}$ in mid-May and moves to $40^{\circ} \mathrm{N}$ in mid-July (Tao and Chen, 1987). Interannual variations in summer precipitation in the Changjiang Basin are mostly controlled by the migration speed and/or timing of the monsoon front in the EASM region. The submillennial- to millennial-scale variations in the Changjiang freshwater discharge could have been related to ENSO-like variability through displacement of the western North Pacific anticyclone as inferred from interannual variations (Liu et al., 2008).

\section{Summary}

We estimated the relative contribution of the Changiiang freshwater in the northern ECS during the Holocene by applying the two-end member mixing model and by considering temporal changes in end member $\delta^{18} \mathrm{O}_{\mathrm{w}}$ of KTW and CFW. We examined the instrumental salinity data in a grid of $31^{\circ}-32^{\circ} \mathrm{N}, 128^{\circ}-129^{\circ} \mathrm{E}$ over the past 50 years (1951-2000), and demonstrated that a robust relationship exists between the relative contribution of Changjiang freshwater $\left(f_{\mathrm{CFW}}\right)$ around a core site in the northern ECS and the Changjiang freshwater discharge $\left(Q_{\mathrm{CFW}}\right)$. The flux of the Changjiang freshwater during the Holocene was reconstructed using this empirical relationship between $f_{\text {CFW }}$ and $Q_{\mathrm{CFW}}$. The reconstructed $Q_{\mathrm{CFW}}$ reveals that there has been no long-term decreasing trend in the Changjiang freshwater discharge since the middle Holocene, indicating that there has been no significant change in EASM precipitation over the Changjiang Basin since this time. This result suggests that temporal changes in regional summer precipitation over the Changjiang Basin during the Holocene did not respond to the orbitally driven summer insolation changes in the Northern Hemisphere. The Supplement related to this article is available online
at doi:10.5194/cp-11-265-2015-supplement.
Acknowledgements. We sincerely thank the scientists and crew of cruise KY07-04. The analyses were supported by the staff at the Mustu Institute of Oceanography (MIO) and Yokosuka headquarter, JAMSTEC, including $\mathrm{H}$. Yamamoto, T. Omura, N. Kisen, Y. Nakamura, M. Kurata, N. Matsuura, A. Miyakubo, and Y. Yoshitomi. We are grateful to K.-Y. Wei, S. Steinke, Y.-P. Chang, and Y. Sun for providing their data, and K. Nagashima and T. Irino for helpful comments. This study was supported through a Japan Society for the Promotion of Science (JSPS) KAKENHI grant (grant number 23221022) awarded to R. Tada and a Grant-in-Aid for JSPS Fellows (grant number 10914) awarded to Y. Kubota. This research was also supported through a grant from the Japan Agency for Marine-Earth Science and Technology (JAMSTEC) through the Ministry of Education, Culture, Sports, Science, and Technology (MEXT, Japan). This is a part of doctoral thesis of Y. Kubota under the guidance of R. Tada and K. Kimoto.

Edited by: L. Beaufort

\section{References}

An, Z., Porter, S. C., Kutzbach, J. E., Wu, X., Wang, S., Liu, X., Li, X., and Zhou, W.: Asynchronous Holocene optimum of the East Asian monsoon, Quaternary Sci. Rev., 19, 743-762, 2000.

Barker, S., Greaves, M., and Elderfield, H.: A study of cleaning procedures used for foraminiferal $\mathrm{Mg} / \mathrm{Ca}$ paleothermometry, Geochem. Geophy. Geosy., 4, 8407, doi:10.1029/2003GC000559, 2003.

Beardsley, R. C., Limburber, R., Yu, H., and Cannon, G. A.: Discharge of the Changjiang (Yangtze River) into the East China Sea, Cont. Shelf Res., 4, 57-55, 1985.

Boyle, E. A. and Keigwin, L. D.: Comparison of Atlantic and Pacific paleochemical records for the last 215000 years: changes in deep ocean circulation and chemical inventories, Earth Planet. Sc. Lett., 76, 135-150, 1985.

Chang, C. P., Zhang, Y., and Li, T.: Interannual and Interdecadal Variations of the East Asian Summer Monsoon and Tropical Pacific SSTs, Part I: Roles of the Subtropical Ridge, J. Climate, 13, 4310-4325, 2000.

Chang, W. Y. B. and King, G.: Centennial climate changes and their global associations in the Yangtze River (Chang Jiang) Delta, China and subtropical Asia, Clim. Res., 2, 95-103, 1994.

Changjiang Water Resources Commission (CWRC): Floods and Droughts in the Yangtze River Catchment, Beijing, 326 pp., 2002.

Chen, C., Beardsley, R. C., Limeburner, R., and Kim, K.: Comparison of winter and summer hydrographic observations in the Yellow and East China Seas and adjacent Kuroshio during 1986, Cont. Shelf Res., 14, 909-928, 1994.

Chen, C. T. A. and Wang, S.-L.: Carbon, alkalinity and nutrient budget on the East China Sea continental shelf, J. Geophys. Res., 104, 20675-20686, 1999.

Chen, M. T., Lin, X. P., Chang, Y. P., Chen, Y. C., Lo, L., Shen, C. C., Yokoyama, Y., Oppo, D. W., Thompson, W. G., and Zhang, R.: Dynamic millennial-scale climate changes in the northwestern Pacific over the past 40000 years, Geophys. Res. Lett., 37, L23603, doi:10.1029/2010GL045202, 2010. 
Cheng, H., Fleitmann, D., Edwards, R. L., Wang, X., Cruz, F. W., Auler, A. S., Mangini, A., Wang, Y., Kong, X., Burns, S. J., and Matter, A.: Timing and structure of the $8.2 \mathrm{kyr}$ B.P. event inferred from ${ }^{18} \mathrm{O}$ records of stalagmites from China, Oman, and Brazil, Geology, 37, 1007-1010, 2009.

Cheng, H., Zhang, P. Z., Spötl, C., Edwards, R. L., Cai, Y. J., Zhang, D. Z., Sang, W. C., Tan, M., and An, Z. S.: The climatic cyclicity in semiarid-arid central Asia over the past 50000 years, Geophys. Res. Lett., 39, L01705, doi:10.1029/2011GL050202, 2012.

Clemens, S. C., Prell, W. L., and Sun, Y.: Orbital-scale timing and mechanisms driving Late Pleistocene Indo-Asian summer monsoons: Reinterpreting cave speleothem $\delta^{18} \mathrm{O}$, Paleoceanography, 25, 19 pp., 2010.

Dansgaard, W.: Stable isotopes in precipitation, Tellus, 16, 436468, 1964.

Dekens, P. S., Lea, D. W., Pak, D. K., and Spero, H. J.: Core top calibration of $\mathrm{Mg} / \mathrm{Ca}$ in tropical foraminifera: Refining paleotemperature estimation, Geochem. Geophy. Geosy., 3, 1-29, 2002.

Delcroix, T. and Murtugudde, R.: Sea surface salinity changes in the East China Sea during 1997-2001: Influence of the Yangtze River, J. Geophys. Res., 107, 9 pp., 2002.

Dilley, M. and Heyman, B. N.: ENSO and disaster: droughts, floods and El Niño/Southern Oscillation warm events, Disasters, 19, 181-193, 1995.

Ding, Y.: Seasonal march of the East-Asian summer monsoon, in: East Asian Monsoon, edited by: Chang, C.-P., World Scientific Publishing Co. Pte. Ltd, Singapore, 3-53, 2004.

Dykoski, C., Edwards, R., Cheng, H., Yuan, D., Cai, Y., Zhang, M., Lin, Y., Qing, J., An, Z., and Revenaugh, J.: A high-resolution, absolute-dated Holocene and deglacial Asian monsoon record from Dongge Cave, China, Earth Planet. Sc. Lett., 233, 71-86, 2005.

Elderfield, H. and Ganssen, G.: Past temperature and $\delta^{18} \mathrm{O}$ of surface ocean waters inferred from foraminiferal $\mathrm{Mg} / \mathrm{Ca}$ ratios, Nature, 405, 442-445, 2000.

Fang, G., Zhao, B., and Zhu, Y.: Water Volume Transport Through the Taiwan Strait and the Continental Skelf of the East China Sea Measured with Current Meters, Elsev Oceanogr. Serie., 54, 345-358, 1991.

Fang, J., Li, Y., Sun, Z., and Deng, J.: Analysis of Runoff Change Characteristics at Datong Station of Yangtze River, Water Resources and Power, 5, 9-12, 2011.

Ge, H., Li, Q., Cheng, X., Zheng, H., and He, J.: Late Quaternary high resolution monsoon records in planktonic stable isotopes from northern South China Sea, Earth Science-Journal of China University of Geosciences, 35, 515-525, 2010.

Hastings, D. W., Kienast, s.s., and Whitko, A. A.: A comparison of three independent paleotemperature estimates from a high resolution record of deglacial SST records in the tropical South China Sea, Eos Trans. AGU, 82, Abstract PP12B-10, 2001.

Hu, C., Henderson, G. M., Huang, J., Xie, S., Sun, Y., and Johnson, K. R.: Quantification of Holocene Asian monsoon rainfall from spatially separated cave records, Earth Planet. Sc. Lett., 266, 221-232, 2008.

Huang, S. and Huang, F.: Spatial-temporal variations of dominant drought/flood modes and the associated atmospheric circulation and ocean events in rainy season over the east of China, Journal of Ocean University of China, 11, 137-146, 2012.

IAEA: GNIP Maps and Animations, 2001.
Ichikawa, H. and Beardsley, R. C.: The Current System in the Yellow and East China Seas, J. Oceanogr., 58, 77-92, 2002.

Inoue, M., Yoshida, K., Minakawa, M., Kiyomoto, Y., Kofuji, H., Nagao, S., Hamajima, Y., and Yamamoto, M.: Spatial variations of ${ }^{226} \mathrm{Ra},{ }^{228} \mathrm{Ra}$, and ${ }^{228} \mathrm{Th}$ activities in seawater from the eastern East China Sea, Geochem. J., 46, 429-441, 2012.

Isobe, A.: Recent Advances in Ocean-Circulation Research on the Yellow Sea and East China Sea Shelves, J. Oceanogr., 64, 569584, 2008.

Isobe, A. and Matsuno, T.: Long-distance nutrient-transport process in the Changjiang river plume on the East China Sea shelf in summer, J. Geophys. Res., 113, C04006, doi:10.1029/2007jc004248, 2008.

Isobe, A., Ando, M., Watanabe, T., Senjyu, T., Sugihara, S., and Manda, A.: Freshwater and temperature transports through the Tsushima-Korea Straits, J. Geophys. Res., 107, 20 pp., 2002.

Jacobs, s.s., Fairbanks, R. G., and Horibe, Y.: Origin and Evolution of Water Masses Near the Antarctic continental Margin: Evidence from $\mathrm{H}_{2}^{18} \mathrm{O} / \mathrm{H}_{2}^{16} \mathrm{O}$ Ratios in Seawater, in: Oceanology of the Antarctic Continental Shelf, edited by: Jacobs, s.s., American Geophysical Union, Washington, D. C., 59-85, 1985.

Japan Oceanographic Data Center (JODC), available at: http: //www.jodc.go.jp/jodcweb/JDOSS/index_j.html (last access: 1 February 2015), 2014.

Jiang, T., Zhang, Q., Zhu, D., and Wu, Y.: Yangtze floods and droughts (China) and teleconnections with ENSO activities, Quat. Int., 144, 29-37, 2006.

Jiang, T., Su, B., and Hartmann, H.: Temporal and spatial trends of precipitation and river flow in the Yangtze River Basin, 19612000, Geomorphology, 85, 143-154, 2007.

Jiang, Z., Yang, S., He, J., Li, J., and Liang, J.: Interdecadal variations of East Asian summer monsoon northward propagation and influences on summer precipitation over East China, Meteorol. Atmos. Phys., 100, 101-119, 2008.

Jin, L., Schneider, B., Park, W., Latif, M., Khon, V., and Zhang, X.: The spatial-temporal patterns of Asian summer monsoon precipitation in response to Holocene insolation change: a model-data synthesis, Quaternary Sci. Rev., 85, 47-62, 2014.

Johnson, K., Hu, C., Belshaw, N., and Henderson, G.: Seasonal trace-element and stable-isotope variations in a Chinese speleothem: The potential for high-resolution paleomonsoon reconstruction, Earth Planet. Sc. Lett., 244, 394-407, 2006.

Kalnay, E., Kanamitsu, M., Kistler, R., Collins, W., Deaven, D., Gandin, L., Iredell, M., Saha, S., White, G., Woollen, J., Zhu, Y., Leetmaa, A., Reynolds, R., Chelliah, M., Ebisuzaki, W., Higgins, W., Janowiak, J., Mo, K. C., Ropelewski, C., Wang, J., Jenne, R., and Joseph, D.: The NCEP/NCAR 40-Year Reanalysis Project, B. Am. Meteorol. Soc., 77, 437-471, 1996.

Kao, S. J., Wu, C.-R., Hsin, Y.-C., and Dai, M.: Effects of sea level change on the upstream Kuroshio Current through the Okinawa Trough, Geophys. Res. Lett., 33, L16604, doi:10.1029/2006g1026822, 2006.

Katoh, O., Morinaga, K., and Nakagawa, N.: Current distributions in the southern East China Sea in summer, J. Geophys. Res.Oceans, 105, 8565-8573, 2000.

Kubota, Y., Kimoto, K., Tada, R., Oda, H., Yokoyama, Y., and Matsuzaki, H.: Variations of East Asian summer monsoon since the last deglaciation based on $\mathrm{Mg} / \mathrm{Ca}$ and oxygen isotope of plank- 
tic foraminifera in the northern East China Sea, Paleoceanography, 25, PA4205, doi:10.1029/2009pa001891, 2010.

Kutzbach, J. E.: Monsoon climate of the early Holocene: climate experiment with the earth's orbital parameters for 9000 years ago, Science, 214, 59-61, 1981.

Kutzbach, J. E., Liu, X., Liu, Z., and Chen, G.: Simulation of the evolutionary response of global summer monsoons to orbital forcing over the past 280000 years, Clim. Dynam., 30, 567-579, 2008.

Lan, Y., Ding, Y., Kang, E., Ma, Q., and Zhang, J.: The relationship between ENSO cycle and high and low-flow in the upper Yellow River, J. Geogr. Sci., 13, 105-111, 2003.

Laskar, J., Robutel, P., Joutel, F., Gastineau, M., Correia, A. C. M., and Levrard, B.: A long-term numerical solution for the insolation quantities of the Earth, Astron. Astrophys., 428, 261-281, 2004.

LeGrande, A. N. and Schmidt, G. A.: Sources of Holocene variability of oxygen isotopes in paleoclimate archives, Clim. Past, 5, 441-455, 2009, http://www.clim-past.net/5/441/2009/.

Lie, H.-J., Cho, C.-H., Lee, J.-H., and Lee, S.: Structure and eastward extension of the Changiiang River plume in the East China Sea, J. Geophys. Res., 108, doi:10.1029/2001jc001194, 2003.

Lin, H.-L., Wang, W.-C., and Hung, G.-W.: Seasonal variation of planktonic foraminiferal isotopic composition from sediment traps in the South China Sea, Mar. Micropaleontol., 53, 447-460, 2004.

Lin, Y.-S., Wei, K.-Y., Lin, I.-T., Yu, P.-S., Chiang, H.-W., Chen, C.-Y., Shen, C.-C., Mii, H.-S., and Chen, Y.-G.: The Holocene Pulleniatina Minimum Event revisited: Geochemical and faunal evidence from the Okinawa Trough and upper reaches of the Kuroshio current, Mar. Micropaleontol., 59, 153-170, 2006.

Liu, J., Wang, B., and Yang, J.: Forced and internal modes of variability of the East Asian summer monsoon, Clim. Past, 4, 225233, 2008, http://www.clim-past.net/4/225/2008/.

Liu, Z., Otto-Bliesner, B., Kutzbach, J., Li, L., and Shields, C.: Coupled Climate Simulation of the Evolution of Global Monsoons in the Holocene, J. Climate, 16, 2472-2490, 2003.

Maher, B. A.: Holocene variability of the East Asian summer monsoon from Chinese cave records: a re-assessment, The Holocene, 18, 861-866, 2008.

Maher, B. A. and Hu, M.: A high-resolution record of Holocene rainfall variations from the western Chinese Loess Plateau: antiphase behaviour of the African/Indian and East Asian summer monsoons, Holocene, 16, 309-319, 2006.

Maher, B. A. and Thompson, R.: Oxygen isotopes from Chinese caves: records not of monsoon rainfall but of circulation regime, J. Quaternary Sci., 27, 615-624, 2012.

Mao, H. L., Ren, Y. W., and Wan, G. M.: A preliminary investigation on the application of using T-S diagrams for the quantitative analysis of the watermasses in the shallow water area, Oceanologia et Limnologia Sinica, 6, 1-22, 1964.

Müller, B., Berg, M., Pernet-Coudrier, B., Qi, W., and Liu, H.: The geochemistry of the Yangtze River: Seasonality of concentrations and temporal trends of chemical loads, Global Biogeochem. Cy., 26, GB2028, doi:10.1029/2011gb004273, 2012.

Nakagawa, T., OKuda, M., Yonenobu, H., Miyoshi, N., Fujiki, T., Gotanda, K., Tarasov, P. E., Morita, Y., Takemura, K., and Horie,
S.: Regulation of the monsoon climate by two different orbital rhythms and forcing mechanisms, Geology, 36, 491-494, 2008.

Nozaki, Y., Tsubota, H., Kasemsupaya, V., Yashima, M., and Ikuta, N.: Residence times of surface water and particle-reactive ${ }^{210} \mathrm{~Pb}$ and ${ }^{210} \mathrm{Po}$ in the East China and Yellow seas, Geochim. Cosmochim. Ac., 55, 1265-1272, 1991.

Oba, T.: Paleoceanographic information obtained by the isotopic measurement of individual foraminiferal specimens, China Ocean Press, Beijing, 169-180, 1990.

O’Neil, J. R., Clayton, R. N., and Mayeda, T. K.: Oxygen Isotope Fractionation in Divalent Metal Carbonates, The Journal of Chemical Physics, 51, 5547-5548, 1969.

Pausata, F. S. R., Battisti, D. S., Nisancioglu, K. H., and Bitz, C. M.: Chinese stalagmite $\delta^{18} \mathrm{O}$ controlled by changes in the Indian monsoon during a simulated Heinrich event, Nat. Geosci., 4, 474-480, 2011.

Saito, Y., Katayama, H., Ikehara, K., Kato, Y., Matsumoto, E., Oguri, K., Oda, M., and Yumoto, M.: Transgressive and highstand systems tracts and post-glacial transgression, the East China Sea, Sediment. Geol., 122, 217-230, 1998.

Schmidt, G. A., LeGrande, A. N., and Hoffmann, G.: Water isotope expressions of intrinsic and forced variability in a coupled ocean-atmosphere model, J. Geophys. Res., 112, D10103, doi:10.1029/2006jd007781, 2007.

Shackleton, N. J.: Attainment of isotopic equilibrium between ocean water and the benthonic foraminifera genus Uvigerina: isotopic changes in the ocean during the last glacial, Cent. Nat. Rech., Sci. Colloq. Int., 219, 203-209, 1974.

Shi, Y., Kong, Z., Wang, S., Tang, L., Wang, F., Yao, T., Zhao, X., Zhang, P., and Shi, S.: Mid-Holocene climates and environments in China, Global Planet. Change, 7, 219-233, 1993.

Steinke, S., Glatz, C., Mohtadi, M., Groeneveld, J., Li, Q., and Jian, Z.: Past dynamics of the East Asian monsoon: No inverse behaviour between the summer and winter monsoon during the Holocene, Global Planet. Change, 78, 170-177, 2011.

Sun, Y., Oppo, D. W., Xiang, R., Liu, W., and Gao, S.: Last deglaciation in the Okinawa Trough: Subtropical northwest Pacific link to Northern Hemisphere and tropical climate, Paleoceanography, 20, PA4005, doi:10.1029/2004pa001061., 2005.

Tan, M.: Climatic differences and similarities between Indian and East Asian Monsoon regions of China over the last millennium: a perspective based mainly on stalagmite records, Int. J. Speleol., 36, 75-81, 2007.

Tao, S. Y. and Chen, L. X.: A review of recent research on the East Asian Summer monsoon in China, in: Monsoon Meteorology, edited by: Tao, S. Y., Oxford University Press, Oxofrd, 60-92, 1987.

Uchida, M., Ohkushi, K. i., Kimoto, K., Inagaki, F., Ishimura, T., Tsunogai, U., TuZino, T., and Shibata, Y.: Radiocarbon-based carbon source quantification of anomalous isotopic foraminifera in last glacial sediments in the western North Pacific, Geochem. Geophy. Geosy., 9, Q04N14, doi:10.1029/2006gc001558, 2008.

Uehara, K., Saito, Y., and Hori, K.: Paleotidal regime in the Changjiang (Yangtze) Estuary, the East China Sea, and the Yellow Sea at $6 \mathrm{kyrBP}$ and $10 \mathrm{kyr}$ BP estimated from a numerical model, Mar. Geol., 183, 179-192, 2002.

Waelbroeck, C., Labeyrie, L., Michel, E., Duplessy, J. C., McManus, J. F., Lambeck, K., Balbon, E., and Labracherie, M.: Sealevel and deep water temperature changes derived from benthic 
foraminifera isotopic records, Quaternary Sci. Rev., 21, 295-305, 2002.

Wang, B., Wu, R., and Fu, X.: Pacific-East Asian Teleconnection: How Does ENSO Affect East Asian Climate?, J. Climate, 13, 1517-1536, 2000.

Wang, B., Yang, J., Zhou, T., and Wang, B.: Interdecadal changes in the major modes of Asian-Australian monsoon variability: Strengthening relationship with ENSO since the late 1970s, J. Climate, 21, 1771-1789, 2008.

Wang, L.: Isotopic signals in two morphotypes of Globigerinoides ruber (white) from the South China Sea: implications for monsoon climate change during the last glacial cycle, Palaeogeogr. Palaeoclimatol. Palaeoecol., 16, 381-394, 2000.

Wang, S.-L. and Chen, C.-T. A.: Bottom water at the center of the north East China Sea in summer: Remnant winter water, Cont. Shelf Res., 18, 1573-1580, 1998.

Wang, Y., Cheng, H., Edwards, R. L., He, Y., Kong, X., An, Z., Wu, J., Kelly, M. J., Dykoski, C. A., and Li, X.: The Holocene Asian monsoon: links to solar changes and North Atlantic climate, Science, 308, 854-857, 2005.

Wang, Y., Cheng, H., Edwards, R. L., Kong, X., Shao, X., Chen, S., Wu, J., Jiang, X., Wang, X., and An, Z.: Millennial- and orbitalscale changes in the East Asian monsoon over the past 224000 years, Nature, 451, 1090-1093, 2008.

Wang, Y. J., Cheng, H., Edwards, R. L., An, Z. S., Wu, J. Y., Shen, C. C., and Dorale, J. A.: A high-resolution absolute-dated late Pleistocene Monsoon record from Hulu Cave, China, Science, 294, 2345-2348, 2001.

$\mathrm{Xu}, \mathrm{K}$., Milliman, J. D., and Xu, H.: Temporal trend of precipitation and runoff in major Chinese Rivers since 1951, Global Planet. Change, 73, 219-232, 2010.

Yamasaki, M., Murakami, T., Tsuchihashi, M., and Oda, M.: Seasonal variation in living planktic foraminiferal assemblage in the northeastern part of the East China Sea, Fossils, 87, 35-46, 2010.
Yuan, D., Cheng, H., Edwards, R. L., Dykoski, C. A., Kelly, M. J., Zhang, M., Qing, J., Lin, Y., Wang, Y., Wu, J., Dorale, J. A., An, Z., and Cai, Y.: Timing, duration, and transitions of the last interglacial Asian monsoon, Science, 304, 575-578, 2004.

Zhang, J., Letolle, R., Martin, J. M., Jusserand, C., and Mouchel, J. M.: Stable oxygen isotope distribution in the Huanghe (Yellow River) and the Changjiang (Yangtze River) estuarine systems, Cont. Shelf Res., 10, 369-384, 1990.

Zhang, J., Chen, F., Holmes, J. A., Li, H., Guo, X., Wang, J., Li, S., Lü, Y., Zhao, Y., and Qiang, M.: Holocene monsoon climate documented by oxygen and carbon isotopes from lake sediments and peat bogs in China: a review and synthesis, Quaternary Sci. Rev., 30, 1973-1987, 2011.

Zhang, L., Liu, Z., Zhang, J., Hong, G. H., Park, Y., and Zhang, H. F.: Reevaluation of mixing among multiple water masses in the shelf: An example from the East China Sea, Cont. Shelf Res., 27, 1969-1979, 2007.

Zhang, Q., Liu, C., Xu, C.-y., Xu, Y., and Jiang, T.: Observed trends of annual maximum water level and streamflow during past 130 years in the Yangtze River basin, China, J. Hydrol., 324, 255265, 2006.

Zhang, Q., Xu, C.-y., Jiang, T., and Wu, Y.: Possible influence of ENSO on annual maximum streamflow of the Yangtze River, China, J. Hydrol., 333, 265-274, 2007.

Zhao, Y. and Harrison, S. P.: Mid-Holocene monsoons: a multimodel analysis of the inter-hemispheric differences in the responses to orbital forcing and ocean feedbacks, Clim. Dynam., 39, 1457-1487, 2011.

Zhou, T., Gong, D., Li, J., and Li, B.: Detecting and understanding the multi-decadal variability of the East Asian Summer Monsoon - Recent progress and state of affairs, Meteorol. Z., 18, 455-467, 2009. 